\title{
MARKET REACTIONS WHEN ZERO-LEVERAGE FIRMS OBTAIN BANK
}

FINANCE

\author{
Andrew Ferguson* and Matthew Grosse
}

University of Technology, Sydney

\begin{abstract}
Prior studies of bank loan announcements depict significant capital market reactions. More recent evidence however, fails to identify such reactions (Fields et al. 2006, Maskara \& Mullineaux 2011). In this study, we consider market reactions to loan initiations where the borrower has no prior record of bank lending. Zero-leverage firms are firms that have zero outstanding short-term or long-term debt in their capital structure (Strebulaev \& Yang 2013). Using a unique hand collected sample of bank loan announcements for Australian Mining Development Stage entities, we find that both initial bank loans and subsequent bank loans attract significant market reactions. Further, we produce evidence consistent with announcements of such loans reducing information asymmetry which we proxy for with bidask spreads and trading volume. Our final analysis examines evidence of bank specialisation. We find that borrowers from the industry leader in terms of loan origination (Macquarie Bank) in this sector exhibit stronger abnormal returns.
\end{abstract}

Keywords; initial bank loans, bank specialisation, market reactions, mining industry

*Corresponding author: Andrew Ferguson, Accounting Discipline Group, UTS, P.O. Box 123 Broadway NSW 2007, Australia.

Phone: +61 295143565

Fax: +61 295143669

Email address: Andrew.Ferguson@uts.edu.au 


\section{Introduction}

Financial intermediation theory suggests banks play an important role in information production within an economy. Banks have private information suggesting they know more about the prospects of the firms they lend to than other external parties. Early empirical evidence provides support for the belief that bank loan agreements act to reduce information asymmetries, and signal positive news to the market. Studies observing a positive share price reaction surrounding bank loan announcements include Mikkelson \& Partch 1986, James 1987 and Lummer \& McConnell 1989. ${ }^{1}$ However, recent studies show that market reactions to bank loan announcements may not be positive, with doubt placed upon the effectiveness of bank loan decisions to signal information to equity investors (Fields et al. 2006; Maskara \& Mullineaux 2011). One possible reason why studies fail to observe positive market reactions might be the distinction between initial and subsequent bank loans. Most empirical studies to date consider samples where bank loan announcements are observed for firms with established credit or borrowing histories.

Our study has three main objectives. First, we aim to provide a better understanding of signalling around bank loan announcements by observing market reactions surrounding zero-leverage firms making initial bank loan announcements. Observing initial loan announcements can indicate whether banks have an information advantage over other capital market participants at the outset of a loan agreement, or whether an information advantage develops from a continuing working relationship with a borrower. Prior studies have concluded that banks enter new credit agreements with no information advantage relative to

\footnotetext{
${ }^{1}$ The ability to minimise information asymmetry problems suggests that banks are unique compared to other sources of external finance (Fama 1985). This is shown empirically as all other forms of security issuances and financing decisions are associated with negative or neutral share price response, examples include seasoned equity offerings (Mikkelson \& Partch 1986), initial public offerings (Loughran \& Ritter 1995), share purchase plans (Brown et al. 2008), private placements of debt (Mikkelson \& Partch 1986) and bond issues (Spiess \& Affleck-Graves 1999).
} 
other investors. However, as banks maintain a lending relationship with their customers, they produce superior information which gives them a relative information advantage over external parties (Lummer \& McConnell 1989). These conclusions are based on samples of observed bank switches and bank loan renewals. In contrast, a loan initiation sample provides an interesting setting to examine whether bank lending decisions can signal superior private information to investors. We argue that observing loan initiations, as opposed to bank switches and renewals as in previous studies, is a better setting in which to observe bank lending signals.

Second, we consider whether bank loans resolve information asymmetry by signalling private information to the market. We analyse changes in the borrowing firm's bid-ask spread and trading volume surrounding bank loan announcements to proxy for changes in the level of information asymmetry. A negative association between bank loans and borrower information asymmetry would be consistent with Fama (1985), who argues that many organizations pay periodic monitoring fees for lines of credit from banks that remain unused, for the sole purpose of providing positive signals about the firm's incomplete contracts. Other literature suggests that the presence of bank debt in firms' capital structures lowers information asymmetry in that it attenuates IPO under-pricing (James \& Wier 1990; Slovin \& Young 1990), negative share price response to SEO's (Slovin et al. 1990) and lowers the cost of debt capital for bond issuances (Datta et al. 1999).

Third, we extend the lender identity literature and investigate whether industry specialist lenders provide incremental signalling benefits. Prior literature has found that higher quality lenders are associated with larger share price reactions upon the announcement of bank loans (Lee \& Sharpe 2009; Ross 2010). Theory indicates that banking industry specialisation should exist with Almazan (2002) suggesting that banks tend to concentrate their portfolios by either region or industry, and that increasing bank expertise in an area can 
lead to decreased information production and monitoring costs. We test whether a subset of industry specialists lenders signal more information to the market around loan announcements compared to non-specialists.

In this study, we examine market reactions to bank loan announcements in a new setting, Australia and in an industry typified by high information asymmetry (the mining industry). Bank loans are theorised to benefit a firm characterised by having no other monitors (Diamond 1984), a poor information environment (Dhaliwal et al. 2011), high information asymmetry (Boyd \& Prescott 1986), low analyst coverage (Best \& Zhang 1993), low auditor impact, high risk (Diamond 1991), and small firm size (Fama 1985). These characteristics broadly describe mining firms (Ferguson et al. 2011a; Ferguson et al. 2011b). Additionally, the majority of mining firms follow a predictable lifecycle and will list on the ASX with zero leverage. This makes mining firms an ideal sample setting to consider the effects of bank financing, as bank loan initiation is both observable and likely to resolve a substantial information asymmetry. If bank loan announcements contain no significant information in a setting where theory predicts reactions will be strong, then it provides support for recent claims that bank loans contain no relevant information (Fields et al. 2006).

We find that both initial and subsequent loan announcements generate significant market reactions in this setting consistent with expectations. Multivariate tests indicate no distinction between loan initiations and subsequent loans, suggesting the banks prior relationship with the borrowing firm is insignificant in explaining announcement returns. Rather, announcement returns are driven by loan characteristics including size of the loan and the sequencing of loan announcements. Further, we find that bank loan announcements are associated with a reduction in firm information asymmetry. Average abnormal trading turnover is significantly positive on the bank loan announcement day, and cumulative average abnormal turnover is significantly positive in the two trading weeks after loan 
announcement. Cumulative average abnormal spread is significantly negative in the two trading weeks following a bank loan announcement. Increased trading volume and decreased bid-ask spread is consistent with a reduction in the borrowing firm's information asymmetry. Last, the industry leader in mine financing in Australia (Macquarie Bank) is associated with larger cumulative average abnormal returns. These results are present in both univariate level and multivariate analysis after controlling for firm and loan characteristics. This result provides support for the hypothesis that industry specialist lenders provide more informative signals about the borrowing firm's creditworthiness and future prospects. The remainder of this paper is structured as follows. The second section details prior literature and research hypothesis. The third section outlines the research design. The fourth section contains empirical results, while the fifth section concludes.

\section{Background and hypothesis development}

There are numerous reasons to expect a positive share price reaction to an announcement of an initial loan. First, theory suggests that banks are better able to screen potential loans relative to outside lenders due to their access to a borrowing firm's private information (Leland \& Pyle 1977). Capital market participants will act on signals provided by information intermediaries only when an intermediary has a sufficient stake in the market to remove incentives to misrepresent their information (Campbell \& Kracaw 1980). Bank loans are a credible signal in this sense since they back their opinions by either allocating or declining resources to borrowers (Fama 1985). Based on the informational advantages banks possess over external parties, and the credibility their lending decisions can signal, investors will gain insight into the quality of a firm's incomplete contracts after loan approval. We argue that initial loan announcements may be associated with more positive share price reaction, since this is the first signal of bank lending credibility sent to the market. 
Second, banks provide ex-post monitoring which can raise the probability of firm success through enforcement of efficient project choice, or the owner's effort (Diamond 1991; Faulkender \& Petersen 2006; Mester et al. 2007). Additionally the bank may take a position on the board of directors (Fama 1985). ${ }^{2}$ Further, banks are more efficient at restructuring firms in financial distress relative to outside lenders (Bolton \& Scharfstein 1996; Bolton \& Freixas 2000). Thus, ex-post monitoring provided by a bank after an initial loan may have a more substantive effect on the borrower's operations than subsequent loans, thus having a greater effect on a borrowing firm's value.

Finally Ross (1977) argues that management is likely to have inside information about the firm value, with firms that are truly high quality having incentives to engage in signalling. Ross (1977) suggests that one such signal may be the firms' use of debt financing. As managers incur a penalty if their firm goes bankrupt, high quality firms will have a higher tolerance for debt than lower quality firms. The implication is that the market should interpret higher debt as a signal of higher value. A special case is of course loan initiation, where a more unambiguous quality signal is being sent, compared to subsequent loans. ${ }^{3},{ }^{4}$

\footnotetext{
${ }^{2}$ An example of a lender requiring a position on the board of directors is shown when Matrix Metals Limited announced the required to appoint a representative to the board of directors as a condition of their $\$ 10$ million loan.

${ }^{3}$ Prior studies examine the information content of 'new' loans and loan renewals, but not loan initiations. For example, Lummer and McConnell (1989) classify a new loan as a firm that arranges a loan with a new bank that they have no previous loan from, stating;

"Except for five cases, all of the firms in our sample that announce new credit agreements had some prior bank financing in place, albeit with a different bank".

This approach was adopted in following studies such as in Slovin et al. (1992) who state;

"New credit agreements with new banks are classified as initiations, even if other bank debt may exist."

${ }^{4}$ We note the distinction between a 'new' loan as described in the literature to date and a 'loan initiation' as we define it may influence results and conclusions of prior papers. Theory predicts bank loan announcements will signal value to outsiders when there are few other intermediaries and information asymmetry is high (Diamond 1984; Boyd \& Prescott 1986). In prior samples, the borrower already had existing bank debt. When a new bank loan is announced with another bank, the new bank duplicates the initial banks screening and monitoring, with little extra information signalled to the market. The result that banks possess no informational advantage at the beginning of a loan (Lummer \& McConnell 1989; Slovin et al. 1992; Best \& Zhang 1993), may be due to sample announcements that miss the loan initiation which is when a firm is first screened and bank monitoring begins. In other words, going from an environment of zero bank-monitoring to having bank monitoring is likely to have a substantially different effect on market perceptions of the firm than an existing borrower obtaining a new loan from a second new bank (simply an additional loan for an already existing borrower).
} 
In summary, we hypothesise that the announcement of a firm obtaining its first bank loan and changing from a zero-leverage capital structure to having private debt, is associated with a positive share price reaction. We pose $\mathrm{H} 1$ as follows:

H1: Initial loan announcements are associated with a positive share price reaction.

Theories of financial intermediation explain the role of banks in reducing information asymmetry. Leland and Pyle (1977) suggest that information asymmetry may be the primary reason that intermediaries exist. Campbell and Kracaw (1980) demonstrate that an important function of financial intermediation is the production of information. These theories argue that banks provide unique information production services (Best \& Zhang 1993). They suggest banks know more about the prospects of the firms they lend to than others. Thus, a bank's lending decision can signal private information to the market and lower the information asymmetry of the borrower.

Bank loans being associated with a reduction in a borrowers information asymmetry is consistent with Fama (1985) in that many organizations pay periodic monitoring fees for lines of credit from banks even though they do not access the finance. The sole purpose of maintaining the loans is to provide positive signals about the firm's incomplete contracts. The presence of bank debt in firms' capital structures is seen to lower information by mitigating IPO under-pricing (James \& Wier 1990; Slovin \& Young 1990), negative share price response to SEO's (Slovin et al. 1990) and lowers the cost of debt capital for bond issuances (Datta et al. 1999). Thus, there is evidence that banks help lower information asymmetry and mitigate adverse selection and moral hazard problems intrinsic to external financing.

However, despite theory predicting banks monitoring will reduce borrower information asymmetry, no study has directly tested whether bank loan announcements are 
associated with such a reduction. If banks mitigate information asymmetry, we expect a reduction in the borrowers bid-ask spread and an increase in trading volume after a bank loan announcement. We test this assertion in the following manner;

H2: Loan announcements are associated with a reduction in firm information asymmetry.

Prior research indicates that lender identity is associated with bank loan announcement returns. Borrowers experience a larger positive abnormal return surrounding bank loan announcements issued by higher quality banks (Billett et al. 1995; Johnson 1997; Lee \& Sharpe 2009; Ross 2010). Ross (2010) defines the three largest banks by market share in the syndicated lending market as high quality, and reports a positive association between loans arranged by the high quality banks and abnormal price reactions around loan announcements. Bushman and Wittenberg-Moerman (2012) find that loans from higher reputation lenders, classified as the six largest banks active in the syndicated loan market are associated with higher firm profitability and credit quality in the subsequent three years to the loan. Lenders may have different monitoring abilities, which enhance a borrower's value by assuring that appropriate investment and spending decisions are implemented (Fama 1985). If negotiating and managing high-risk loans (with many covenants to be designed and enforced) requires different skills than low-risk credits, individual lenders may choose to specialize (Billett et al. 1995). We extend this literature by testing whether a mining specialist lender signals more information about the borrower to outside investors.

Industry specialisation and leadership has been shown to exist amongst financial intermediaries such as underwriters (Carter \& Manaster 1990; Booth \& Chua 1996), auditors (Craswell et al. 1995; Ferguson \& Stokes 2002; Ferguson et al. 2003) and non-financial assurers (Ferguson \& Pundrich 2013). Almazan (2002) reports that banks tend to concentrate their portfolios by either region or industry, and that increasing bank specialisation can lead 
to decreased information production and monitoring costs due to learning.Winton (1999) shows that banks benefit from specialisation due to more effective monitoring of borrowers, leading to decreased adverse selection costs. Empirical support for these claims is provided by Acharya et al. (2006) who show that specialist banks have higher returns and lower risk than diversified banks, due to improved information production and monitoring capabilities.

The existence of bank industry specialisation is expected to occur in settings with high information asymmetry (Bonaccorsi di Patti \& Dell'Ariccia 2004). High information asymmetry leads to banks carving out a captive market by overinvesting in information acquisition, enhancing lending efficiency and leading to excessive information production (Hauswald \& Marquez 2006). Thus, the Australian MDSE setting is ideal to test for the effects of banking industry specialisation due to the high level of information asymmetry and specialist geological knowledge required to understand a mining project. Anecdotal evidence supports the existence of banking industry specialisation within the mining industry in Australia. ${ }^{5}$ We predict that specialist lenders will signal more private information to outside investors leading to higher bank loan announcement returns. This hypothesis can be formally stated as:

\footnotetext{
5 A resource analyst from Emerging Trends (2010) commenting on a mining firms chance of obtaining bank financing states;

"Between the failure of Opes Prime, the withdrawal of Societe Generale and the scaled back operations of ABN Amro, a lingering after effect of the global financial crisis is that mining finance in Australia is largely in the hands of Macquarie Bank, which now has a near monopoly on project finance." Borrowers are also cognisant of the of the market leading position of Macquarie Bank as this quote from Saracen Resources shows;

"We are pleased to advise the market about the facilities from Macquarie, which is a leader in this segment of the resources sector. The Finance Facilities bring substantial benefits to Saracen... This is a solid outcome for our shareholders, and gives us significant financial flexibility."

Additionally, Macquarie Bank market themselves as an industry leader in resource financing. Macquarie Bank state they are the "global leader in financing the resources infrastructure sector." Further quotes from the Macquarie Bank website refer to their specialisation within the industry;

"Macquarie Capital's Resources team combines financial services and specialised industry knowledge with a focus on companies operating globally in the resources sector, particularly the mining and metals, energy and related services sectors... This specialisation provides miners with the ability to efficiently finance new or existing capital intensive infrastructure to focus on their core businesses."
} 
H3: Firms that receive loans from an industry specialist will have higher abnormal

bank loan announcement returns relative to loans received from non-industry-specialists.

\section{Research Design}

\subsection{Sample \& data}

This study draws on a sample of listed Australian MDSEs. The sample period used for this study spans September 1998 to July 2013. ${ }^{6}$ Text searches of ASX announcements serve as the primary source of bank loan announcement identification. The characteristics of each announced loan are hand collected from the bank loan announcement documents. Capital market data such as daily price, bid, ask, volume and market capitalisation is obtained from Datasteam. Firm level financial data is obtained from Aspect Huntley. Analyst information is extracted from the Institutional Brokers' Estimate System (I/B/E/S).

Table displays the sample size of both initial and subsequent loan announcements. An initial loan is defined as a loan issued by a zero-leverage firm initiating its first debt position. A subsequent loan is defined as a loan issued to a firm who has a positive debt level prior to the loan announcement. A total of 216 initial loan announcements and 191 subsequent loan announcements are identified in the period 1998 to 2013 . $^{7}$ These announcements are made by 126 and 96 unique companies respectively. ${ }^{8}$

\subsection{Loan announcement returns}

Abnormal returns are calculated as:

$A R_{i, t}=\ln \left[\frac{P_{i, t}}{P_{i, t-1}}\right]-\ln \left[\frac{P_{m, t}}{P_{m, t-1}}\right]$

\footnotetext{
${ }^{6}$ The ASX announcements search tool available in DatAnalysis Premium allows for text searches of announcements archived after September 1998. Thus all readily available data is used to create the sample. ${ }^{7}$ Announcement frequency is increasing in time. This is expected, since there are an increasing numbers of firms listed in the mining industry in the second half of the sample period due to the mining boom. The frequency of announcements is relatively stable in the period from 2006 to 2012; probably due to lag effects from the boom continuing into the GFC period (mining projects are notoriously long in terms of duration).

${ }^{8}$ The number of unique companies making initial loan announcements is less than the total number of announcements. Firms may make multiple announcements regarding a single bank loan to the market.
} 
where; $A R_{i, t}$ is the abnormal return of firm $i$ at time $t$, with time $t$ being the event date of a bank loan announcement, $P_{i, t}$ is the share price of firm $i$ at time $t$ and $P_{m, t}$ is the index value of the All Ordinaries at time $t .{ }^{9}$ The cumulative abnormal return from event day $q$ to event day $s$ is the summation of the abnormal returns, calculated as:

$\operatorname{CAR}_{i, t}(q, s)=\sum_{t=q}^{s} A R_{i, t}$

\subsection{Model specification}

In order to provide additional insight into the cross-sectional variation of the abnormal returns surrounding bank loan announcements, an OLS regression model is used. This model is specified as follows;

$$
\operatorname{CAR}_{i, t}(q, s)=\beta_{0}+\beta_{1} \text { Initial }+\beta_{2} \text { FirstAnn }+\beta_{3} \text { LnAmount }+\beta_{4} \text { Lenders }+
$$

$\beta_{5}$ Hedge $+\beta_{6}$ BankEquity $+\beta_{7}$ EquityRaise $+\beta_{8}$ LnMCap $+\beta_{9}$ Loss +

$\beta_{10}$ NumAnalyst $+\varepsilon$

where; the dependent variable, $C A R_{i, t}(q, s)=$ the cumulative abnormal return for firm $i$ at time $t$ over the window $q$ to $s$, calculated as per (2). Initial represents a binary variable capturing whether the loan is an initial loan. An initial loan is defined as the first loan a firm obtains as it changes its capital structure from a zero-leverage firm to a positive leverage firm. FirstAnn is a binary variable equal to one if the announcement is the first announcement regarding a particular loan. FirstAnn is predicted to be positively associated with abnormal returns, as the first announcement made to the market regarding a loan should contain the most new, and price sensitive information. LnAmount is calculated as the dollar amount of borrowed funds scaled by the borrowing firm's total assets in the period prior to the loan announcement. A positive association is expected between the amount of funds borrowed and

\footnotetext{
${ }^{9}$ All prices are adjusted for changes in the basis of quotation, such as dividends on the ex-dividend day.
} 
the abnormal market reaction. A larger loan represents a stronger vote in confidence of the firm's creditworthiness by the bank, and signals positive news about the firm.

Lenders is the number of lenders mentioned in the bank loan announcement. A negative association is expected between the number of lenders and abnormal returns. As the number of lenders increases, the ability of banks to renegotiate debt when a firm is distressed decreases (Preece \& Mullineaux 1996). Hedge is a binary variable equal to 1 if it is disclosed within the bank loan announcement that commodity or foreign exchange hedging is required before a loan agreement can be completed. Hedging might have a positive or negative sign. On the positive side, hedging improves certainty regarding future firm cash flows and lowers firm risk, especially where the project has a high cost of production. However equity investors may potentially lose any upside or option value from commodity price fluctuations and consider it a burden on future profitability in times of rising commodity prices. BankEquity is a binary variable equal to 1 if it is disclosed within the bank loan announcement that the bank owns shares, warrants or options in the borrowing firm. A positive association is predicted between banks holding equity in the firm and providing a loan. If a bank holds an equity position, it is a signal that they believe the firm has potential upside. EquityRaise is a binary variable equal to 1 if it is disclosed within the bank loan announcement that the bank requires the borrowing firm to raise further equity before a loan agreement can be completed. If a bank loan is dependent on the firm issuing more equity, a negative coefficient is expected as equity raisings are associated with negative share price reactions (Mikkelson \& Partch 1986).

LnMCAP measures firm size and is calculated as the natural logarithm of the firm's market capitalisation 5 days before the bank loan announcement. Firm size is expected to have a negative relation with abnormal returns. Smaller firms are expected to have higher levels of information asymmetry and benefit more from bank finance signals (Fama 1985; 
Diamond 1989; Slovin et al. 1992). Loss is a binary variable equal to 1 if the firm reported a net profit after tax of less than zero in the annual report prior to the bank loan announcement. Loss is expected to have a positive association with announcement returns. Firms issued a loan while making losses are likely to have a larger gain in creditworthiness if a bank signals the firm is able to pay back future loaned funds. Finally, NumAnalyst is the number of analysts following firm $i$ on the announcement date of a loan. A negative associated between the number of analysts following a firm and its abnormal returns surrounding a bank loan announcement is predicted. An increasing number of analysts covering a firm represent an improved information environment and reduction in information asymmetry. Bank loans are predicted to signal more information when information asymmetry is high.

\subsection{Information asymmetry}

Two proxies are used to measure changes in information asymmetry. First, the bid-ask spread addresses the adverse selection problem that arises from transacting in firm shares in the presence of asymmetrically informed investors. Less information asymmetry implies less adverse selection, which, in turn, implies a smaller bid-ask spread (Leuz \& Verrecchia 2000). Second, trading volume is a measure of liquidity that captures the willingness of some investors who hold firm shares to sell and the willingness of others to buy. This willingness to transact in firm shares should be inversely related to the existence of information asymmetries (Leuz \& Verrecchia 2000). When investors' beliefs converge about the value of the firm, there is an increase in trading turnover in the firm's stock (Diamond \& Verrecchia 1991). Consistent with this proposition, Easley et al. (1996) present evidence that suggests high turnover stocks have lower information based trading. Turnover is therefore used as a measure of a firm's level of information asymmetry with increases in turnover associated with a decrease in information asymmetry. 


\section{Bid-Ask spread}

We examine Hypothesis 2 by testing for changes in the borrowing firm's information asymmetry in the period surrounding a bank loan announcement. The abnormal change in the bid-ask spread is measured as:

$$
\begin{aligned}
& \operatorname{SPREAD}_{i, t}=\left[\frac{\left(\text { AskPrice }_{i, t}-\text { BidPrice }_{i, t}\right)}{1 / 2\left(\text { AskPrice }_{i, t}+\text { BidPrice }_{i, t}\right)}\right] \\
& \operatorname{ESPREAD}_{i, t}(p, q)=\frac{\sum_{t=p}^{q} \operatorname{SPREAD}_{i, t}}{(q-p)}
\end{aligned}
$$

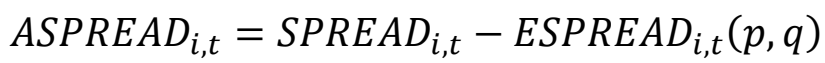

$S P R E A D_{i, t}$ is the daily average bid-ask spread for firm $i$ on day $t$ calculated as the

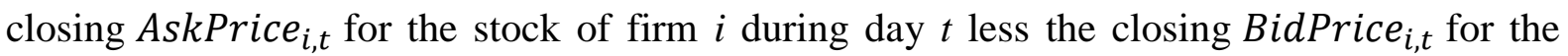
stock of firm $i$ divided by the closing mid-point price. $E S P R E A D_{i, t}$ is the average daily bidask spread for the stock of firm $i$ over days $q$ to $s . A S P R E A D_{i, t}$ is the abnormal bid-ask spread, calculated as the difference between $S P R E A D_{i, t}$ and the $E S P R E A D_{i, t}$. In the main results, $p$ and $q$ are $t$-100 and $t$-15, respectively. To examine if changes in abnormal bid-ask spread are significantly different from zero, student $t$-tests are calculated.

The cumulative average abnormal spread from event day $q$ to event day $s$ is the summation of the abnormal spread, calculated as:

$$
\operatorname{CAAS}_{i, t}(q, s)=\sum_{t=q}^{s} A S P R E A D_{i, t}
$$

\section{Trading Volume}

The event study methodology is adopted to analyse whether a firm's abnormal trading turnover is significantly different from zero following a bank loan announcement. Abnormal turnover is calculated as:

$$
\begin{aligned}
& \operatorname{TURN}_{i, t}=\frac{\operatorname{VOL}_{i, t}}{\text { HShares }_{i, t}} \\
& \operatorname{ETURN}_{i, t}(p, q)=\frac{\sum_{t=p}^{q} \operatorname{VOL}_{i, t} /(q-p)}{\# \operatorname{Shares}_{i, t}}
\end{aligned}
$$




$$
\operatorname{ATURN}_{i, t}=\operatorname{TURN}_{i, t}-\operatorname{ETURN}_{i, t}(p, q)
$$

$T U R N_{i, t}$ is the turnover of the stock of firm $i$ on day $t$, calculated as the volume of shares traded for firm $i$ on day $t\left(V O L_{i, t}\right)$, divided by the number of ordinary shares outstanding for firm $i$ on day $t$ (\#Shares $\left.s_{i, t}\right)$. ETURN $N_{i, t}$ is the average daily turnover for the stock of firm $i$ at time $t$ over days $p$ to $q$. ATURN $N_{i, t}$ is the abnormal turnover of firm $i$ at time $t$, calculated as the difference between $T U R N_{i, t}$ and $E T U R N_{i, t}$. In the main results, $p$ and $q$ are $t-90$ and $t-16$, respectively. To examine if changes in abnormal turnover are significantly different from zero, student $t$-tests are calculated. The cumulative average abnormal turnover from event day $q$ to event day $s$ is the summation of the abnormal turnover, calculated as:

$$
\operatorname{CAAT}_{i, t}(q, s)=\sum_{t=q}^{s} A T U R N_{i, t}
$$

\subsection{Lender industry specialisation}

We examine Hypothesis 3 at the univariate level comparing event study results of loans issued by banks considered industry specialists with a sample of loans issued by banks considered non-industry specialists. Statistical differences between the two samples are compared using student $t$-tests. Next, OLS regression is used to examine the multivariate determinants of the abnormal return experienced surrounding bank loan announcements. To determine if industry specialist banks signal more information to equity investors relative to non-specialist banks, the model specification described in Equation (3) is altered to include the variable Macquarie as follows;

$$
\begin{aligned}
& \quad \operatorname{CAR}_{i, t}(q, s)=\beta_{0}+\beta_{1} \text { Macquarie }+\beta_{2} \text { Initial }+\beta_{3} \text { FirstAnn }+\beta_{4} \text { LnAmount }+ \\
& \beta_{5} \text { Lenders }+\beta_{6} \text { Hedge }+\beta_{7} \text { BankEquity }+\beta_{8} \text { EquityRaise }+\beta_{9} \text { LnMCap }+\beta_{10} \text { Loss }+ \\
& \beta_{11} \text { NumAnalyst }+\varepsilon
\end{aligned}
$$


where: All variables are defined as previously outlined in equation (3) except for the new test variable Macquarie. Macquarie is a dummy variable coded ' 1 ' if a bank loan has been issued by Macquarie Bank, the bank classified as a mining industry specialist, and '0' otherwise.

\section{Results}

\subsection{Descriptive statistics}

Descriptive statistics are reported in Table 2, with Panel A reporting descriptives for firms announcing initial loans and Panel B reporting descriptives for firms announcing subsequent loans. Firms announcing an initial loan are significantly smaller than firms announcing subsequent loans, with the median market capitalisation $(M C A P)$ of a firm announcing an initial loan is approximately $\$ 80$ million, (\$195 million for firms announcing subsequent loans). Median total assets (Total Assets) for the initial loan sample are $\$ 30$ million (\$115 million for firms announcing subsequent loans). Median total book value of equity (Total Equity) is $\$ 27$ million for the initial loan sample ( $\$ 79$ million for the subsequent loan sample). All three size measures show firms announcing initial loans to be smaller than firms announcing subsequent loans.

The level of debt between the two samples, not surprisingly, is vastly different. Bank loans are classified as initial loans if the borrowing firm is a zero-leverage firm. Thus the short-term and long-term debt of the loan initiation sample is zero. Firms obtaining subsequent loans have prior debt (median borrowings of over $\$ 5$ million). ${ }^{10}$ Both samples report a median net profit (Net Profit After Tax) of approximately negative \$2 million. This suggests that the majority of borrowing firms in both samples are loss making firms.

\footnotetext{
${ }^{10}$ There are two reasons why the minimum debt position of the subsequent loan sample is reported as zero. First, a firm may have zero long-term debt, while still have positive short-term debt and vice versa. Second, as debt levels are taken from the annual report prior to the loan announcement, there are constituents in the sample who have obtained an initial loan and subsequent loan in the same financial year. Thus observing the debt position from the prior financial report would result in an observation of zero debt, as the initial loan was entered into during the reporting period and is not yet disclosed in the financial statements.
} 
Descriptive statistics on the loss indicator, Loss, shows that $84.36 \%$ of firms in the initial loan sample are loss making firms (65.61\% in the subsequent loan sample).

Firms announcing an initial loans and are shown to be younger in age, average firm age is 1,868 days (4,749 for subsequent loans), and have higher information asymmetry with a median spread (AvgSpread) that is $3.01 \%$ (2.40\% for firms announcing subsequent loans) larger and median turnover (AvgTurnover) $0.20 \%$ (0.20\% for firms announcing subsequent loans). Initial loan announcing firms have fewer information intermediaries with an average of 1.62 fewer analysts (NumAnalyst) following the firm. Additionally fewer initial loan firms have any analyst coverage (Analyst)or Big 4 auditors (Big4) with coverage of $39.53 \%$ and $59.07 \%$ respectively $(55.03 \%$ and $68.78 \%$ for firms announcing subsequent loans) Overall these descriptive statistics show that firms announcing initial loans have an information environment that is characterised by high information asymmetry.

Overall the descriptive statistics describe a sample with characteristics that support the notion that the signalling benefits provided by an outside lender should matter. Sample firms are small as measured by market capitalisation, total assets and total equity and relatively risky as evidenced by their poor profitability records. Information asymmetry is relatively high due to low analyst coverage, and the presence of many non-Big 4 auditors.

\subsection{Borrower descriptive statistics}

Loan descriptive statistics are reported in Table 3Table. The size of the average loan issued to an initial borrower (Amount), is $\$ 76$ million ( $\$ 159$ million for subsequent loans, more than double the amount borrowed by zero-leverage MDSEs). Consistent with the loan initiation sample consisting of smaller firms, the amount borrowed is under half the average for subsequent borrowers. The median loan of $\$ 31$ million suggests a zero-leverage firm will have a debt to equity ratio of approximately $50 \%$ after securing a loan. A significant variation 
in loan size is present within both samples. Minimum loan amounts of $\$ 1$ million represent relatively small loans, even for the firms with the smallest market capitalisation, however at the upper end of the spectrum, multi-billion dollar loans are observed to fund large projects. The median and average loan term (Maturity) in both samples is between 3 to 4 years representing loans of a medium term nature. The majority of loans in both samples are issued by a single lender (Number of lenders). ${ }^{11}$

A common way banks monitor firms is through the use of loan covenants and within this sample there are two common covenants. Over $25 \%$ of loan initiations (18\% of subsequent loans) require commodity or foreign exchange hedging (Hedging) to be implemented by the lender. The requirement to hedge production or currency risk alters the project pay-off and is an example of bank monitoring potentially lowering firm risk. Additionally, over $10 \%$ of loans were conditional upon the borrowing firm raising further equity (EquityRaising) before drawdown to ensure the borrowing firm maintained a suitable debt to equity ratio.

Finally, the variable BankEquity indicates that $28 \%$ of initial loans and $22 \%$ of subsequent loans were issued to borrowers where the lender had either stock, warrant or option positions. Banks having an equity or option position in the borrower can be interpreted as an endorsement of the firm's future prospects as banks look to access the firm's future upside.

\footnotetext{
${ }^{11}$ The terms of the loan disclosed in announcements varies significantly. Over $95 \%$ of firms disclose the number lenders (Number of lenders) and the amount (Amount) of the loan. However disclosure of other material items is less pervasive, with only $46 \%$ of initial loans and $57 \%$ of subsequent loans disclosing the maturity of the loan (Maturity). Less than 25\% of firms disclosed the interest rate (Interest rate) of the loan at the time of announcement with many firms stating lack of disclosure to be due to commercial confidence. Of the firms which disclosed the interest rate, the majority of loans are based on variable interest rates with a fixed margin over the London Interbank Offered Rate (LIBOR).
} 


\subsection{Lender descriptive statistics}

Within the sample of loan announcements 121 unique lenders are identified, with 635 lender observations across the total sample. ${ }^{12}$ Table 4 presents the top 40 lenders sorted by the number of loans issued. The most striking feature of Table 4 is the dominance of Macquarie Bank, who wrote 70 mining project bank loans, a clear market leader in terms of loan frequency. Macquarie Bank wrote more than double the number of loans compared to ANZ Bank (33). Macquarie Bank's industry leadership depicted in Table 4 is consistent with anecdotal evidence documented in footnote 5. .Table 4 displays the total value of loans issued, with Macquarie Bank ranked in $3^{\text {rd }}$ with over $\$ 3$ billion in loans issued. ${ }^{13}$

\subsection{Loan announcement return}

Table 5, Panel A reports abnormal returns during the -5 to 5 day window for the full sample of bank loan announcements. A significantly positive abnormal return of $2.051 \%$ is observed on the announcement date (T0), consistent with prior studies (James 1987; Lummer \& McConnell 1989; Best \& Zhang 1993). Panel B reports results for initial loan announcements. Results are supportive of Hypothesis 1, with initial bank loan announcements being associated with a significantly positive abnormal return of $2.480 \%$ on the announcement date. This result contrasts prior studies that find 'new' loans do not attract a significant market response (Lummer \& McConnell 1989; Best \& Zhang 1993). Table 5, Panel C reports a significantly positive abnormal return of $1.551 \%$ on the event date for subsequent loan announcements.

\footnotetext{
12 The number of lender observations is larger than the total sample size due to loan syndication in which more than one lender is identified in a single announcement.

${ }^{13}$ China Development Bank is the $2^{\text {nd }}$ largest lender in the industry in terms of loan size with outstanding loans of $\$ 3,468,000,000$. This figure is driven by three large loans valued close to a billion dollars each. Additionally the strong performance in total loaned funds by Credit Suisse and ANZ is due to having single loans worth over $\$ 1$ billion each.
} 
We consider whether the abnormal return surrounding bank loan announcements persists over a longer event window, with the cumulative average abnormal return (CAAR) calculated in (2) over the -5 to 5 event day window. Table 6 Panel A displays the CAAR for the total sample of bank loan announcements over various windows. The significantly positive -5 to 5 day CAAR of $2.518 \%$ is driven by the market response in the 0,1 event window. The -5 to -2 day CAAR is small and insignificant, suggesting no information leakage prior to loan announcements. Similarly, the 2 to 5 day CAAR is also small and insignificant. Table, Panel B presents CAARs for the sample of initial loan announcements. Results further support Hypothesis 1 , with the -5 to 5 day CAAR a significantly positive $2.732 \%$. The abnormal return observed in the -1 to 1 day window is maintained during the following trading week, with little evidence of significant returns in the pre event window. Table 6 Panel $\mathrm{C}$ provides evidence that the subsequent loan announcements behave in a manner similar to the initial loan sample, with a significantly positive CAAR of $2.268 \%$ observed over the -5 to 5 day event window, and little evidence of either significant pre or post announcement returns or mean reversion. ${ }^{14}$

Univariate results testing Hypothesis 1 are provided in Table 5 and Table 6, with results strongly supporting hypothesis 1 , with initial bank loan announcements are associated with a positive share price response. The positive share price response is observed on both the event day AAR, and over a -5 to 5 day CAAR. This result shows that bank lending decisions do provide unambiguous signals to equity market participants. This result contrasts with prior research that finds banks do not signal information to equity markets upon the announcement of a 'new' loan (Lummer \& McConnell 1989; Slovin et al. 1992; Best \& Zhang 1993) which

\footnotetext{
${ }^{14}$ In unreported test the initial loan sample AAR is $0.93 \%$ larger and significantly different from the subsequent loan sample at a 5\% level of significance on event day zero. The difference in CAAR -5 to 5 day event window shows the initial loan sample to have a larger abnormal return than the subsequent loan sample; however results are not statistically significant.
} 
is often just a switch in lenders. Subsequent loan announcements have a positive market reaction, albeit lower in magnitude than initial loan announcements.

\subsection{Market reaction determinants}

We regress bank loan and firm characteristics on the cumulative abnormal return surrounding the 0 to $1,-5$ to 5 and -10 to 10 day event windows. ${ }^{15}$ Table 7 presents our crosssectional returns prediction with three models presented where the dependent variable cumulative average abnormal return is defined over the 0 to 1 (Panel A), -5 to 5 (Panel B) and -10 to 10 (Panel C) day windows. All three models are significant at the $p<0.01 \%$ level with $F$-statistics greater than 2.5. Results in Panel A shows the coefficients (with the exception of LnMCap) have the predicted signs. Significant predictors of abnormal return include whether the announcement is the first in the sequence of announcements (FirstAnn), the amount borrowed (LnAmount), and whether the bank has an equity position in the borrowing firm (BankEquity). LnAmount provides the strongest predictor of abnormal returns with a positive coefficient of 0.18 , significant at $p<0.000$. This indicates that relatively larger loans are associated with higher abnormal returns. FirstAnn has a positive coefficient of 0.28 , significant at $p<0.001$. A firm's first announcement regarding its bank loan contains the most new information, and the price response is most positive for these announcements. If a bank has an equity position in the borrowing firm (BankEquity), it is associated with a more positive price reaction, with a coefficient of 0.016 , although is only marginally significant at conventional levels $(p=0.10)$. This is consistent with the argument that banks are attracted to the potential future project upside. Additionally the variable Hedge has a negative coefficient of $-0.015, p$-value of 0.115 . Although only marginally significant, this suggests hedging

\footnotetext{
${ }^{15}$ In unreported tests a correlation matrix shows that multi-collinearity does not appear to be a concern. Significant correlations are under 0.4 for all variables except for LnMCap which is correlated with NumAnalyst and LnAmount. Furthermore, in unreported tests all variance inflations factors on primary multivariate models reported in Table are below 1.5.
} 
lowers future project upside by eliminating option value associated with a rise in commodity prices.

Table 7, Panel B presents results over the event window -5 to 5 . The explanatory power of the model decreases, with the adjusted $\mathrm{R}$ squared of 0.056 lower than presented in Panel A. Once again, FirstAnn and LnAmount remain significant predictors of announcement returns with coefficients of 0.026 and 0.18 . EquityRaise and NumAnalyst are also significant. EquityRaise has a positive coefficient of 0.061, significant at $p<0.05$. A loan announcement that mentions further equity issuance is required as a condition precedent is associated with a more positive reaction. Slovin et al. (1990) find that firms with bank debt have a lower negative price reaction to SEO's. This result suggests that investors are encouraged by the signal of the banks monitoring, with the condition of a further equity issue perhaps signalling more project good news. Consistent with predictions that the firm information environment is an important determinant of loan announcement returns, NumAnalyst has a negative coefficient of -0.005 with a significance level $p<0.043$. Firms with more analysts have lower information asymmetry, with bank loan signals less important where other financial intermediaries are present. Table 7, Panel C depicts results over the -10 to 10 day event window. The model obtains an adjusted R squared of 0.040. FirstAnn maintains a positive coefficient of 0.045 and significance at $p<0.040$. BankEquity, EquityRaise and NumAnalyst are all significant predictors with significance levels similar to those reported in Panel B. In summary, results suggest that the amount borrowed (LnAmount), whether the bank also has an equity position in the borrowing firm (BankEquity), whether an equity issuance is required (EquityRaise) and the number of analysts following the borrowing firm (NumAnalyst) are significant at predicting announcement returns. Whether an announcement is the first mention of a bank loan announcement is also highly significant (FirstAnn). We make the observation that recent studies suggesting bank loans have no impact on the capital 
market may not have be accounted for information leakage through sequential information release (Maskara \& Mullineaux 2011). The results for FirstAnn suggests the market reacts well before an official loan sign off.

Contrary to expectations, Initial is not significant in the multivariate context.

Univariate results suggesting initial loan reactions are stronger than reactions to subsequent loan announcements do not hold in the multivariate tests after controlling for firm and loan characteristics. Our results suggest banks are able to successfully produce private information during the screening process, but the signals provided during subsequent loans are just as salient as those provided by initial loans after controlling for firm and loan characteristics.

\subsection{Information asymmetry}

\section{Average abnormal turnover}

Figure 3 presents the average abnormal turnover surrounding bank loan announcements. Results across all three samples are displayed in Panels A, B and C, and depict a sharp positive spike in AATO on the day of a bank loan announcement. Table 8 presents the average abnormal turnover and significance tests surrounding bank loan announcements during the -10 to 10 day event window. Bank loan announcements are associated with a statistically significant increase in average abnormal turnover on the event date, with a $0.123 \%$ increase in turnover observed on the event date. The initial loan sample is associated with a larger increase in abnormal turnover relative to the subsequent loan sample, with initial loan announcements experiencing a $0.142 \%$ increase in daily abnormal turnover and subsequent loans experiencing a $0.102 \%$ increase in daily abnormal turnover. A cumulative average abnormal turnover over the 0 to 10 day period shows a significantly positive turnover of $0.256 \%$ in the post announcement window for the total sample, while the -10 to -1 event window experiences insignificant changes in abnormal turnover. These results suggest 
trading volume increases in the period after the announcement of a bank loan, consistent with Hypothesis $2 .^{16}$

Table 10, Panel A presents results of an OLS regression with cumulative abnormal turnover in the -10 to 10 day event window as the dependent variable. The model is significant with an $F$-statistic of 2.8 and significant at $p<0.002$. An adjusted R squared of 0.046 is reported. Significant predictors of cumulative average abnormal turnover are FirstAnn, BankEquity and EquityRaise. FirstAnn has a coefficient of 0.008 significant at $p<0.009$ and suggests that the increase in a firms turnover is largest when the first loan announcement is released. If the bank has an equity position in the borrowing firm BankEquity a lower increase in abnormal turnover is observed. EquityRaise is positive with a coefficient of 0.013 , significant at $p<0.005$ and. If the firm announces it will be raising more equity capital in the future as part of the loan conditions, abnormal turnover increases. After controlling for the characteristics of the borrowing firm and loan agreement, Initial is not significant. This suggests that both samples of bank loan announcements are associated with a reduction in information asymmetry, with both initial and subsequent loans able to signal private information about the firm's future to equity investors.

\section{Average abnormal spread}

Table 9 presents the average abnormal spread over the -10 to 10 day event window. Panel A, $\mathrm{B}$ and $\mathrm{C}$ display results for the total sample, initial sample and subsequent loan sample respectively. A negative abnormal spread is observed on the announcement day and following event day in all three samples. Table 9 presents the average abnormal spread and tests of statistical significance. Abnormal spreads decrease on the announcement day for all

\footnotetext{
${ }^{16}$ In unreported tests, the statistical significance of differences between the average abnormal turnover of the initial loans sample and the subsequent loans sample is compared. Over both the -1 to 1 and -5 to 5 event windows, initial loan announcements experienced a significantly larger average abnormal turnover relative to the subsequent loan sample. Results suggest that both initial and subsequent loan announcements are associated with an increase in abnormal trading turnover, however consistent with the event study results, reactions are larger for the initial loan sample of firm than for the subsequent loan sample of firms.
} 
three samples, although not at a statistically significant level. Event day 1 experiences a reduction in abnormal spread of $-0.524 \%$ significant at $p<0.05,-0.0546 \%$ significant at $p<0.01$ and $-0.0499 \%$ significant at $p<0.005$ for the total, initial and subsequent sample of announcements respectively. The total sample experiences a cumulative average abnormal spread that is significantly negative in the 1 to 10 day post announcement period, with cumulative spread reducing by $-3.165 \%$, significant at $p<0.10$. This result suggests that bank loan announcements result in a decrease in spread that persists over two trading weeks after the loan is announced. During the -10 to -1 event pre-event window, cumulative average abnormal spread is insignificant across the three samples. ${ }^{17}$ Overall, the decrease in average abnormal spread reported in Table 9 is interpreted as showing a decrease in the firm's level of information asymmetry after making a bank loan announcement. These results are consistent with other studies showing that firms experience a decrease in bid-ask spread after releasing material disclosures to the market (Raman \& Tripathy 1993; Boone 1998; Leuz \& Verrecchia 2000; Schauer 2002).

Table 10, Panel B presents the results of an OLS regression with cumulative average abnormal spread over the -10 to 10 day event window as the dependent variable. The model obtains an adjusted $\mathrm{R}$ squared of 0.042 , significant at $p<0.006$. Variables explaining changes to abnormal spread are Lenders, LnMCap, and Loss. Lenders is significantly negative with a coefficient of $-0.031, p=0.031$. A negative coefficient suggests that as the number of lenders increases, the spread decreases. LnMCap, is positive with a coefficient of 0.033 , significant at $\mathrm{P}<0.011$ larger firms have a smaller reduction in information asymmetry after announcing a bank loan. Loss is significantly negative with a coefficient of -0.056 significant at $p<0.067$, loss making firms have a larger reduction in information asymmetry after a bank loan

\footnotetext{
${ }^{17}$ In unreported tests of significance between the abnormal spread of the initial and subsequent loan sample, no significant difference is found across the -3 to 3 day event window between the two samples. This result suggests that both the initial and subsequent loan sample of firms benefit from a decrease in bid-ask spread after bank loan announcements.
} 
announcement. The results for Loss and LnMCap are consistent with the expectation that smaller firms will benefits from the signal of creditworthiness provided by a bank's loan decision.

In summary, these results provide support for Hypothesis 2 as firms experience an increase in average abnormal turnover and a decrease in average abnormal spread on the event date of a bank loan announcement. Turnover is higher, and spread is lower in the 10 day post-announcement period relative to the 10 day pre-announcement period. Thus the theories of financial intermediation that suggest banks play an important role in reducing information asymmetry are supported by our results.

\subsection{Industry specialisation}

We classify Macquarie Bank as the industry leader with Table 11 displaying the cumulative average abnormal return for the sample of loans issued by Macquarie Bank compared to the sample of loans issued by non-industry specialist lenders. Larger returns are depicted surrounding loans issued by Macquarie Bank in the three event windows considered. Over the -5 to 5 day event window, loans to Macquarie Bank experience a cumulative average abnormal return of $5.053 \%$ compared to the $1.89 \%$ return experienced by firms borrowing from non-industry specialist lenders. Tests of significance between the two samples show this difference in returns is significant at the 5\% level. Despite Macquarie Bank loans experiencing the predicted larger cumulative average abnormal return over the other two event windows, tests are not significant.

Table 12 presents our augmented OLS regression model including an industry leadership variable (Macquarie). Three models are presented with the dependent variable being the cumulative average abnormal return in the 0 to $1,-5$ to 5 and -10 to 10 day event windows in Panels A, B and C respectively. All three models are significant at $p<0.01 \%$ with 
$F$-statistics greater than 3. Panel A presents results for the 0,1 event window. Macquarie is insignificant in explaining abnormal returns over the two day event window. This is consistent with the univariate results presented in Table 12 which showed significant differences in announcement returns only developed over longer event windows. Consistent with results presented in Table 7, FirstAnn, LnAmount and BankEquity remain significant predictors of loan announcement returns with positive and significant coefficients.

Panel's B and C of Table 12 both provide evidence of industry leadership influencing loan announcement returns. Panel B shows that during the -5 to 5 day event window Macquarie has a positive coefficient of 0.032 and is significant at $p<0.10$. Panel $\mathrm{C}$ shows that over the longer event window, Macquarie is the most important predictor of loan announcement returns over the -10 to 10 window, with a coefficient of 0.078 , significant at $p<0.05$. As in prior analysis, other significant predictors are FirstAnn with a coefficient of 0.048 and significant at $p<0.029$ suggesting that the first loan announcement in a sequence of announcements is the most informative. EquityRaise with a coefficient of 0.064 significant at $p<0.071$ and NumAnalyst with a coefficient of -0.009 significant at $p<0.018$ displaying that firms with a weaker information environment experience larger loan announcement returns.

In summary, univariate evidence presented in Table 11, and multivariate evidence presented in Table 12 provide support for $\mathrm{H} 3$ over longer event windows. Over a short 0 to 1 day event window, industry leadership is not significantly associated with an increased announcement abnormal return. Over a -5 to 5 day event window, Macquarie Bank loans have an abnormal return of $5.053 \%$, statistically significant in the test of differences at $p<0.042$. After controlling for borrowing firm characteristics and loan characteristics using OLS regression this result remains, and strengthens over the -10 to 10 day event window. Consistent with prior studies, bank lender identity is a significant determinant of abnormal returns surrounding bank loan announcements (Billett et al. 1995; Ross 2010). Ross (2010) 
presents evidence that loans from larger banks are associated with higher abnormal returns, which our evidence in relation to Macquarie Bank's specialisation in this setting supports.

\section{Summary and conclusions}

Using a hand collected sample of bank loan announcements disclosed by Australian MDSE's, we provide evidence that bank loan announcements can signal important price sensitive information regarding the borrowing firm's inside information. We consider three research questions. First do initial loans matter more than subsequent loans. Second, do loans result in reduced information asymmetry and third, does a specialist lender matter. We find Zeroleverage firms initiating a banking relationship experience a significant and positive abnormal return of $2.480 \%$ on the day a loan announcement is released, and experience a positive cumulative average abnormal return of $2.732 \%$ during the -5 to 5 day event window surrounding loan announcements. Despite univariate evidence consistent with initial bank loans having stronger market reactions, our proxy is not significant in multivariate analysis. Rather, firm and loan characteristics such as disclosure sequencing, the amount borrowed, equity positions in the borrower and the number of analysts covering the firm are all important predictors of announcement returns. In a multivariate setting, both initial and subsequent loans are important capital market signals in this setting.

In terms of our second research question relating to information asymmetry, our results show that bank loan announcements are associated with an increase in abnormal trading turnover, and a decrease in abnormal bid-ask spread. An increase in turnover and a decrease in spread are consistent with a reduction in the borrowing firm's information asymmetry. We suggest that banks signalling their private information regarding the borrowing result in an improved information environment in the capital market.

Last, consistent with prior research suggesting that bank lender identity is associated with bank loan announcement returns (Ross 2010), we investigate whether loans issued by 
the industry leader Macquarie Bank result in stronger market reactions. Univariate results support this assertion, with borrowers obtaining loans from Macquarie Bank experience a significantly larger cumulative average abnormal return in the -5 to 5 day event window relative to loans issued by non-leaders. Multivariate results support this finding after controlling for other firm and loan characteristics.

In contrast to recent evidence suggesting bank loans are not informative, our results suggest bank loans convey strongly positive signals regarding the borrowers future prospects. Our study provides further out of US sample evidence on bank loan announcements, and the first evidence on the importance of private debt financing in the mining industry. This industry is characterised by high information asymmetry, arguably a good setting in which to observe important distinctions such as loan initiation and lender specialisation. Given the importance of bank financing in the mining industry, our study suggests more can be learnt from future industry studies, which have desirable experimental attributes (Shevlin, 1996). 
Tables and figures

\section{Table 1 Sample}

\begin{tabular}{cccc}
\hline & Companies & Announcements & Period \\
\hline Initial loans & 126 & 216 & $25 / 02 / 1998$ to $02 / 04 / 2013$ \\
& & & \\
Subsequent loans & 96 & 191 & $23 / 03 / 1998$ to $16 / 07 / 2013$ \\
& & & - \\
Total sample & 163 & 407 & $25 / 02 / 1998$ to $16 / 07 / 2013$
\end{tabular}

Table displays the number of observations in the Initial loans and Subsequent loans sample and the period in time in which the loan announcement are observed. Companies' represents the number of unique companies in the sample. Announcements' represents the number of different announcements observed. 
Table 2 Borrower descriptive statistics

Panel A: Initial loans sample firm descriptive statistics

\begin{tabular}{|c|c|c|c|c|c|}
\hline Continuous variables & Mean & Median & Std. Dev. & Min & Max \\
\hline MCAP & $190,290,424.53$ & $79,270,000.00$ & $249,688,105.04$ & $4,380,000.00$ & $1,113,540,000.00$ \\
\hline Total Assets & $68,041,264.43$ & $30,433,001.00$ & $94,500,611.18$ & $25,244.00$ & $812,924,000.00$ \\
\hline Short Term Debt & - & - & - & - & - \\
\hline Long Term Debt & - & - & - & - & - \\
\hline Total Equity & $57,911,514.43$ & $27,564,170.00$ & $79,022,679.98$ & $16,828,451.00$ & $642,125,000.00$ \\
\hline Net Profit After Tax & $-4,869,309.04$ & $-2,068,000.00$ & $29,044,846.81$ & $-285,292,000.00$ & $169,996,000.00$ \\
\hline AvgTurnover & $0.26 \%$ & $0.20 \%$ & $0.22 \%$ & $0.00 \%$ & $1.01 \%$ \\
\hline AvgSpread & $4.11 \%$ & $3.01 \%$ & $3.66 \%$ & $0.71 \%$ & $23.82 \%$ \\
\hline Age & 1868.78 & 2600.00 & 3042.11 & 0.00 & 16218.00 \\
\hline NumAnalyst & 0.82 & 0.00 & 1.51 & 0.00 & 13.00 \\
\hline Binary Variable & & & yes & $\%$ yes & \\
\hline Loss & & & 178 & $84.36 \%$ & \\
\hline Analyst & & & 85 & $39.53 \%$ & \\
\hline Big4 & & & 127 & $59.07 \%$ & \\
\hline
\end{tabular}


Panel B: Subsequent loans sample descriptive statistics

\begin{tabular}{|c|c|c|c|c|c|}
\hline Continuous variables & Mean & Median & Std. Dev. & Min & Max \\
\hline MCAP & $890,162,928.18$ & $195,050,000.00$ & $2,916,446,307.42$ & $5,200,000.00$ & $32,201,200,000.00$ \\
\hline Total Assets & $502,489,017.83$ & $115,157,417.00$ & $1,652,763,281.91$ & $2,866,022.00$ & $19,070,464,767.00$ \\
\hline Long Term Debt & $111,605,280.13$ & $4,351,820.00$ & $513,637,813.78$ & - & $4,336,296,675.00$ \\
\hline Short Term Debt & $19,158,828.21$ & $1,459,955.00$ & $43,340,105.72$ & - & $267,139,157.00$ \\
\hline Total Equity & $297,755,172.70$ & $79,277,533.00$ & $990,957,329.47$ & $24,441,000.00$ & $12,685,021,125.00$ \\
\hline Net Profit After Tax & $14,447,878.17$ & $-2,273,139.00$ & $137,895,463.13$ & $-207,521,651.00$ & $956,794,330.00$ \\
\hline AvgTurnover & $0.27 \%$ & $0.20 \%$ & $0.32 \%$ & $0.00 \%$ & $3.31 \%$ \\
\hline AvgSpread & $2.91 \%$ & $2.40 \%$ & $2.09 \%$ & $0.45 \%$ & $13.09 \%$ \\
\hline Age & 4749.78 & 3984.00 & 3567.65 & 9.00 & 18018.00 \\
\hline NumAnalyst & 2.44 & 1.00 & 4.24 & 0.00 & 20.00 \\
\hline
\end{tabular}

\begin{tabular}{lll}
\hline Binary Variable & yes & \% yes \\
\hline Loss & 124 & $65.61 \%$ \\
Analyst & 104 & $55.03 \%$ \\
Big4 & 130 & $68.78 \%$ \\
\hline
\end{tabular}

Table, Panel A provides descriptive statistics for Initial loan observations; Panel B provides descriptive statistics for Subsequent loan observations. MCAP is the market capitalization of firm $i$ as on day $t-15$ in dollars. Total Asset is the reported total assets of firm $i$ in the annual report released prior to the bank loan announcement measured in dollars. Long Term Debt is the reported long term debts of firm $i$ in the annual report released prior to the bank loan announcement measured in dollars. Short Term Debt is the reported short term debts of firm $i$ in the annual report released prior to the bank loan announcement measured in dollars. Total Equity is the reported total equity of firm $i$ in the annual report released prior to the bank loan announcement measured in dollars. Net Profit After Tax is the reported net profit after tax of firm $i$ in the annual report released prior to the bank loan announcement measured in dollars. AvgTurnover is the average turnover of firm $i$ in the period -100 to -15 days before a loan announcement. AvgSpread is the average bid-ask spread of firm $i$ in the period -100 to -15 days before a loan announcement. Age is measured in days, and is calculated as the number of days between a firms listing date and loan announcement. NumAnalyst is the number of analysts following firm $i$ on the day it made a loan announcement. Loss is a binary variable equal to one if the firm had a net profit after tax of less than zero. Analyst is a binary variable equal to one if the firm had an analyst covering them on the date of their bank loan announcement. Big4 is a binary variable equal to one if the annual report released of firm $i$ was audited by a big four auditing firm in the period prior to their bank loan announcement. 
Table 3 Loan descriptive statistics

Panel A: Initial loan sample loan descriptive statistics

\begin{tabular}{|c|c|c|c|c|c|c|c|}
\hline Continuous variables & Mean & Median & Std. Dev. & Min & Max & Count Disclosed & \% Disclosed \\
\hline Amount & $76,384,201.42$ & $31,000,000.00$ & $163,693,587.21$ & $1,000,000.00$ & $1,200,000,000.00$ & 211 & $97 \%$ \\
\hline Maturity & 53.57 & 48.00 & 37.48 & 2.00 & 156.00 & 100 & $46 \%$ \\
\hline Number of lenders & 1.42 & 1.00 & 0.87 & 1.00 & 6.00 & 212 & $98 \%$ \\
\hline
\end{tabular}

\begin{tabular}{lrl}
\hline Binary Variable & Yes & \% Yes \\
\hline Interest rate & 41 & $18.89 \%$ \\
Hedging & 56 & $25.81 \%$ \\
BankEquity & 61 & $28.11 \%$ \\
EquityRaising & 23 & $10.60 \%$ \\
\hline
\end{tabular}

Panel B: Subsequent loan sample descriptive statistics

\begin{tabular}{|c|c|c|c|c|c|c|c|}
\hline Continuous variables & Mean & Median & Std. Dev. & Min & Max & Count Disclosed & $\%$ Disclosed \\
\hline Amount & $159,140,351.07$ & $58,750,000.00$ & $389,775,642.92$ & $1,000,000.00$ & $4,500,000,000.00$ & 188 & $99 \%$ \\
\hline Maturity & 44.49 & 36.00 & 30.17 & 3.00 & 144.00 & 109 & $57 \%$ \\
\hline Number of lenders & 1.78 & 1.00 & 1.18 & 1.00 & 7.00 & 181 & $95 \%$ \\
\hline
\end{tabular}

\begin{tabular}{lrr}
\hline Binary Variable & Yes & \% Yes \\
\hline Interest rate & 44 & $23.16 \%$ \\
Hedging & 35 & $18.42 \%$ \\
BankEquity & 43 & $22.63 \%$ \\
EquityRaising & 11 & $5.79 \%$ \\
\hline
\end{tabular}

Table, Panel A provides descriptive statistics regarding the loans issued to the initial loan sample. Panel B provides descriptive statistics regarding the loans issued to the subsequent loan sample. Amount is represents the disclosed amount to be borrowed by the firm measured in dollars. Maturity represents the number of months until the loan must be paid back in full. Number of lenders represents the number of lenders that are disclosed to be providing the loan. Interest Rate is a binary variable equal to one if the interest rate payable on the loan is disclosed in the bank loan announcement. Hedging is a binary variable equal to one if the bank loan announcement discloses that the borrowing firm is required to undertake commodity or foreign exchange hedging. BankEquity is a binary variable equal to one if the bank loan announcement discloses that the lending firm has a stock or option position in the borrowing firm. EquityRaising is a binary variable equal to one if the bank loan announcement discloses that the borrowing firm is required to undertake an equity issuance. 
Table 4 Lender frequency

\begin{tabular}{|c|c|c|c|}
\hline Bank & Number of loans & \multicolumn{2}{|c|}{ Aggregate Value of Loans } \\
\hline Macquarie Bank & 70 & $\$$ & $3,198,550,001.00$ \\
\hline ANZ Bank & 33 & $\$$ & $3,694,519,047.62$ \\
\hline Commonwealth Bank of Australia & 30 & $\$$ & $1,089,325,000.00$ \\
\hline Standard Bank & 28 & $\$$ & $1,151,133,333.33$ \\
\hline Investec & 27 & $\$$ & $1,253,952,380.95$ \\
\hline Rand Merchant Bank & 27 & $\$$ & $509,350,000.00$ \\
\hline Bank of Scotland & 25 & $\$$ & $848,666,666.67$ \\
\hline Societe Generale & 24 & $\$$ & $697,366,666.67$ \\
\hline Credit Suisse & 21 & $\$$ & $3,196,000,000.00$ \\
\hline BNP Paribas & 21 & $\$$ & $1,456,400,000.00$ \\
\hline Barclays Bank & 20 & $\$$ & $590,785,714.29$ \\
\hline Standard Chartered Bank & 18 & $\$$ & $1,101,766,666.67$ \\
\hline China Development Bank & 13 & $\$$ & $3,468,000,000.00$ \\
\hline Westpac & 13 & $\$$ & $283,091,666.67$ \\
\hline Deutsche Bank & 12 & $\$$ & $479,000,000.00$ \\
\hline National Australia Bank & 12 & $\$$ & $398,000,000.00$ \\
\hline Rothschild Australia & 12 & $\$$ & $79,666,666.67$ \\
\hline Nedbank & 11 & $\$$ & $112,000,000.00$ \\
\hline WestLB & 10 & $\$$ & $236,000,000.00$ \\
\hline ABN Amro & 8 & $\$$ & $204,000,000.00$ \\
\hline European Investment Bank & 7 & $\$$ & $320,700,000.00$ \\
\hline Bank West & 7 & $\$$ & $130,416,666.67$ \\
\hline Caterpillar Financial Services & 7 & $\$$ & $76,000,000.00$ \\
\hline Bank of China & 5 & $\$$ & $818,000,000.00$ \\
\hline Sumitomo Mitsui Banking Corporation & 5 & $\$$ & $362,500,000.00$ \\
\hline International Finance Corp & 5 & $\$$ & $282,500,000.00$ \\
\hline HSBC & 5 & $\$$ & $121,333,333.33$ \\
\hline Beyerische Hypo-und Vereinsbank & 5 & $\$$ & $34,000,000.00$ \\
\hline Industrial and Commercial Bank of China & 4 & $\$$ & $305,000,000.00$ \\
\hline ABSA Bank South Africa & 4 & $\$$ & $75,616,500.00$ \\
\hline Resource Capital Funds & 4 & $\$$ & $20,000,000.00$ \\
\hline Dresdner Bank & 3 & $\$$ & $160,033,333.33$ \\
\hline EIG Global Energy Partners & 3 & $\$$ & $1,000,000,000.00$ \\
\hline Goldman Sachs & 3 & $\$$ & $404,166,666.67$ \\
\hline Korea Exchange Bank Australia & 3 & $\$$ & $265,000,000.00$ \\
\hline Raiffeisen Zentrallbank Osterreich & 3 & $\$$ & $260,000,000.00$ \\
\hline Royal Bank of Scotland & 3 & $\$$ & $134,200,000.00$ \\
\hline Sprott Resource Lending & 3 & $\$$ & $26,000,000.00$ \\
\hline Trafigura & 3 & $\$$ & $127,000,000.00$ \\
\hline
\end{tabular}

Table displays the top 40 banks sorted by the number of loans issued. Aggregate value of loans is calculated as the sum of all the loans issued by a particular bank in the sample. 
Table 5 Daily average abnormal returns (AAR) surrounding bank loan announcements

\begin{tabular}{|c|c|c|c|c|c|c|}
\hline \multirow[b]{2}{*}{ Event Day } & \multicolumn{2}{|c|}{ Panel A: All loans } & \multicolumn{2}{|c|}{ Panel B: Initial Bank Loans $(n=212)$} & \multicolumn{2}{|c|}{ Panel C: Subsequent Loans ( $n=182)$} \\
\hline & AAR & t-stat & AAR & t-stat & AAR & t-stat \\
\hline-5 & $0.229 \%$ & 1.035 & $0.421 \%$ & 1.273 & $0.006 \%$ & 0.021 \\
\hline-4 & $0.000 \%$ & -0.001 & $0.103 \%$ & 0.298 & $-0.119 \%$ & -0.395 \\
\hline-3 & $-0.088 \%$ & -0.444 & $0.073 \%$ & 0.258 & $-0.276 \%$ & -1.011 \\
\hline-2 & $0.116 \%$ & 0.599 & $0.233 \%$ & 0.866 & $-0.019 \%$ & -0.069 \\
\hline-1 & $-0.108 \%$ & -0.550 & $-0.208 \%$ & -0.749 & $0.009 \%$ & 0.034 \\
\hline 0 & $2.051 \%$ & $7.273^{* * *}$ & $2.480 \%$ & $5.755^{* * *}$ & $1.551 \%$ & $4.495^{* * *}$ \\
\hline 1 & $0.469 \%$ & 1.489 & $0.481 \%$ & 1.019 & $0.456 \%$ & 1.123 \\
\hline 2 & $0.041 \%$ & 0.174 & $-0.055 \%$ & -0.174 & $0.153 \%$ & 0.423 \\
\hline 3 & $0.306 \%$ & 1.359 & $0.154 \%$ & 0.431 & $0.482 \%$ & $1.876 *$ \\
\hline 4 & $-0.349 \%$ & -1.641 & $-0.615 \%$ & $-2.348^{* *}$ & $-0.041 \%$ & -0.119 \\
\hline 5 & $-0.150 \%$ & -0.691 & $-0.337 \%$ & -1.042 & $0.067 \%$ & 0.240 \\
\hline
\end{tabular}

Panel A presents the daily average abnormal returns (AAR) surrounding the total sample of bank loan announcements. Panel B presents the AAR surrounding initial bank loan announcements. Panel C presents the AAR surrounding subsequent bank loan announcements. AAR is calculated as outlined in equation (1). Student t-statistics are presented to show if the AAR is significantly different from zero. $\mathrm{N}$ is the number of observations. Event Day ' 0 ' represents the day of the bank loan announcement. Two tailed tests of significance are reported as follows $* * *$ less than $0.01 * *$ less than 0.05 and $*$ less than 0.10 . 


\section{Table 6 Cumulative average abnormal returns surrounding bank loan}

\section{announcements.}

Panel A: Cumulative average abnormal returns surrounding the total sample of bank loan announcements.

\begin{tabular}{llllrr}
\hline Event Day & CAAR & t-stat & N & Count Positive & \% Positive CAAR \\
\hline $\mathbf{- 5}$ to $\mathbf{5}$ & $2.518 \%$ & $\mathbf{3 . 5 5 2} * * *$ & 396 & 222 & $56.06 \%$ \\
$\mathbf{- 3}$ to $\mathbf{3}$ & $2.787 \%$ & $\mathbf{4 . 6 5 7 * * *}$ & 396 & 226 & $57.07 \%$ \\
$\mathbf{- 1}$ to $\mathbf{1}$ & $2.412 \%$ & $\mathbf{5 . 8 4 0 * * *}$ & 396 & 244 & $61.61 \%$ \\
$\mathbf{0}$ to $\mathbf{1}$ & $2.520 \%$ & $\mathbf{6 . 2 8 5 * * *}$ & 396 & 259 & $65.40 \%$ \\
$\mathbf{- 5}$ to $-\mathbf{2}$ & $0.257 \%$ & 0.658 & 396 & 188 & $47.47 \%$ \\
$\mathbf{2}$ to $\mathbf{5}$ & $-0.151 \%$ & -0.371 & 396 & 188 & $47.47 \%$ \\
\hline
\end{tabular}

Panel B: Cumulative average abnormal returns surrounding initial bank loan announcements.

\begin{tabular}{llllrr}
\hline Event Day & CAAR & t-stat & N & Count Positive & \% Positive AR \\
\hline $\mathbf{- 5}$ to $\mathbf{5}$ & $2.732 \%$ & $\mathbf{2 . 7 2 8} * * *$ & 213 & 120 & $56.33 \%$ \\
$\mathbf{- 3}$ to $\mathbf{3}$ & $3.158 \%$ & $\mathbf{3 . 5 8 7 * * *}$ & 213 & 122 & $57.27 \%$ \\
$\mathbf{- 1}$ to $\mathbf{1}$ & $2.753 \%$ & $\mathbf{4 . 6 9 6 * *}$ & 213 & 131 & $61.50 \%$ \\
$\mathbf{0}$ to $\mathbf{1}$ & $2.961 \%$ & $\mathbf{5 . 1 3 1} * * *$ & 213 & 143 & $67.13 \%$ \\
$\mathbf{- 5}$ to $\mathbf{- 2}$ & $0.828 \%$ & 1.448 & 213 & 105 & $49.29 \%$ \\
$\mathbf{2}$ to $\mathbf{5}$ & $-0.849 \%$ & -1.494 & $\mathbf{2 1 3}$ & 87 & $40.84 \%$ \\
\hline
\end{tabular}

Panel C: Cumulative average abnormal returns surrounding subsequent loan announcements.

\begin{tabular}{llllrr}
\hline Event Day & CAAR & t-stat & N & Count Positive & \% Positive AR \\
\hline $\mathbf{- 5}$ to $\mathbf{5}$ & $2.268 \%$ & $\mathbf{2 . 2 6 9 * *}$ & 183 & 102 & $55.73 \%$ \\
$\mathbf{- 3}$ to $\mathbf{3}$ & $2.355 \%$ & $\mathbf{2 . 9 6 9 * * *}$ & 183 & 104 & $56.83 \%$ \\
$\mathbf{- 1}$ to $\mathbf{1}$ & $2.015 \%$ & $\mathbf{3 . 4 8 8 * * *}$ & 183 & 113 & $61.74 \%$ \\
$\mathbf{0}$ to $\mathbf{1}$ & $2.006 \%$ & $\mathbf{3 . 6 5 9 * * *}$ & 183 & 116 & $63.38 \%$ \\
$\mathbf{- 5}$ to $\mathbf{- 2}$ & $-0.409 \%$ & -0.792 & 183 & 83 & $45.35 \%$ \\
$\mathbf{2}$ to $\mathbf{5}$ & $0.661 \%$ & 1.147 & 183 & 101 & $55.19 \%$ \\
\hline
\end{tabular}

Table Panel A presents the cumulative average abnormal returns (CAAR) surrounding the total sample of bank loan announcements. Panel B presents the cumulative average abnormal returns (CAAR) surrounding the initial bank loan sample of announcements. Panel $\mathrm{C}$ presents the cumulative average abnormal returns (CAAR) surrounding the subsequent bank loan sample of announcements. CAAR is calculated as outlined in equation (2). Student t-statistics are presented to show if the CAAR is significantly different from zero. $\mathrm{N}$ is the number of observations. Count Positive is the number of announcements with a positive AAR. \% Positive CAAR is calculated as Count Positive divided by $\mathrm{N}$, to represent the $\%$ of firms with a positive cumulative abnormal reaction on the event day. Event Day '0' represents the day of the bank loan announcement. Two tailed tests of significance are reported as follows $* * *$ less than $0.01 * *$ less than 0.05 and $*$ less than 0.10 . 
Table 7 Determinants of market reaction around bank loan announcements

\begin{tabular}{|c|c|c|c|c|c|c|c|c|c|c|}
\hline \multirow{2}{*}{ (Constant) } & \multirow{2}{*}{\begin{tabular}{|l} 
Predicted \\
Sign \\
\end{tabular}} & \multicolumn{3}{|c|}{ Panel A: 0 to +1} & \multicolumn{3}{|c|}{ Panel B: -5 to 5} & \multicolumn{3}{|c|}{ Panel C: -10 to 10} \\
\hline & & $\begin{array}{l}\text { Coeff } \\
.003\end{array}$ & $\begin{array}{l}\text { t-stat } \\
.042\end{array}$ & $\begin{array}{l}\text { p-value } \\
.967\end{array}$ & $\begin{array}{l}\text { Coeff } \\
.019\end{array}$ & $\begin{array}{l}\text { t-stat } \\
.153\end{array}$ & $\begin{array}{l}\text { p-value } \\
.879\end{array}$ & $\begin{array}{l}\text { Coeff } \\
-.033\end{array}$ & $\begin{array}{l}\text { t-stat } \\
-.184\end{array}$ & $\begin{array}{l}\text { p-value } \\
.854\end{array}$ \\
\hline Initial & + & .005 & .588 & .557 & -.012 & -.829 & .408 & -.011 & -.517 & .606 \\
\hline FirstAnn & + & .028 & $3.200^{\star * \star}$ & .001 & .026 & $1.670^{\star}$ & .096 & .045 & $2.064^{\star \star}$ & .040 \\
\hline Lenders & - & -.001 & -.319 & .750 & .011 & 1.433 & .153 & .002 & .199 & .842 \\
\hline Hedge & ? & -.015 & -1.578 & .115 & -.006 & -.340 & .734 & -.022 & -.899 & .369 \\
\hline BankEquity & + & .016 & $1.637^{\star}$ & .100 & .024 & 1.368 & .172 & .041 & $1.637^{\star}$ & .100 \\
\hline EquityRaise & - & -.007 & -.510 & .610 & .061 & $2.444^{\star \star}$ & .015 & .063 & $1.759^{\star}$ & .079 \\
\hline LnMCAP & - & .001 & .314 & .754 & -.001 & -.153 & .879 & .000 & .047 & .963 \\
\hline \multirow{2}{*}{\multicolumn{2}{|c|}{$\begin{array}{l}\text { F-stat } \\
\text { Adjusted R2 } \\
\text { N }\end{array}$}} & .079 & & & .056 & & & .040 & & \\
\hline & & 374 & & & 374.000 & & & 374 & & \\
\hline
\end{tabular}

Table presents Ordinary Least Squares regressions on the determinants of the cumulative average abnormal return around the release of a bank loan announcement. Panel A reports results over the event windows 0 to 1 , Panel B reports results over the event window -5 to 5 and Panel C reports results over the event window -10 to 10.

Regression variables are defined as: Initial represents a binary variable capturing if the loan is an initial loan. FirstAnn is a binary variable equal to one if the announcement is the first in a sequence of announcements. LnAmount is calculated as the dollar amount of borrowed funds scaled by the borrowing firm's total assets in the period prior to the loan announcement. Lenders is the number of lenders mentioned in the bank loan announcement. Hedge is a binary variable equal to 1 if it is disclosed within the bank loan announcement that the bank requires the borrowing to hedge its commodity or foreign exchange exposure before a loan agreement can be completed. BankEquity is a binary variable equal to 1 if it is disclosed within the bank loan announcement that the bank owns shares, warrants or options of the borrowing firm. EquityRaise is a binary variable equal to 1 if it is disclosed within the bank loan announcement that the bank requires the borrowing firm to raise further equity before a loan agreement can be completed. LnMCap is the natural logarithm of the firm's market capitalisation 15 days before the bank loan announcement. Loss is a binary variable equal to 1 if the firm reported a net profit after tax of less than zero in the annual report prior to the bank loan announcement. NumAnalyst is the number of analysts following firm $i$ on the announcement date. p-values are provided based on two-tailed tests of significance. 
Table 8 Average abnormal turnover surrounding bank loan announcements.

\begin{tabular}{|c|c|c|c|c|c|c|}
\hline \multirow[b]{2}{*}{ Event Day } & \multicolumn{2}{|c|}{ Total sample $(n=362)$} & \multicolumn{2}{|c|}{$\begin{array}{c}\text { Initial sample } \\
\quad(n=193)\end{array}$} & \multicolumn{2}{|c|}{ Subsequent sample $(n=169)$} \\
\hline & AATO & t-stat & AATO & t-stat & AATO & t-stat \\
\hline-10 & $0.007 \%$ & 0.372 & $0.020 \%$ & 0.794 & $-0.008 \%$ & -0.310 \\
\hline-9 & $0.005 \%$ & 0.230 & $0.011 \%$ & 0.348 & $-0.002 \%$ & -0.101 \\
\hline-8 & $0.039 \%$ & 1.066 & $0.011 \%$ & 0.382 & $0.073 \%$ & 0.997 \\
\hline-7 & $0.016 \%$ & 0.685 & $0.034 \%$ & 1.003 & $-0.005 \%$ & -0.142 \\
\hline-6 & $-0.024 \%$ & $-1.970 * *$ & $-0.015 \%$ & -0.902 & $-0.034 \%$ & $-1.932 *$ \\
\hline-5 & $-0.012 \%$ & -0.674 & $0.015 \%$ & 0.516 & $-0.044 \%$ & $-2.594 * *$ \\
\hline-4 & $0.017 \%$ & 0.630 & $0.024 \%$ & 0.571 & $0.008 \%$ & 0.274 \\
\hline-3 & $0.011 \%$ & 0.458 & $0.034 \%$ & 0.820 & $-0.014 \%$ & -0.569 \\
\hline-2 & $0.022 \%$ & 0.934 & $0.047 \%$ & 1.251 & $-0.007 \%$ & -0.241 \\
\hline-1 & $-0.001 \%$ & -0.030 & $-0.004 \%$ & -0.175 & $0.004 \%$ & 0.159 \\
\hline 0 & $0.123 \%$ & $4.735^{* * *}$ & $0.142 \%$ & $3.621 * * *$ & $0.102 \%$ & $3.069 * * *$ \\
\hline 1 & $0.080 \%$ & $3.261 * * *$ & $0.129 \%$ & $3.128 * * *$ & $0.024 \%$ & 1.049 \\
\hline 2 & $0.060 \%$ & $1.955^{*}$ & $0.069 \%$ & $1.706 *$ & $0.050 \%$ & 1.054 \\
\hline 3 & $0.011 \%$ & 0.511 & $0.055 \%$ & 1.563 & $-0.039 \%$ & -1.506 \\
\hline 4 & $0.012 \%$ & 0.473 & $0.045 \%$ & 1.047 & $-0.026 \%$ & -1.120 \\
\hline 5 & $-0.021 \%$ & -1.187 & $-0.020 \%$ & -1.063 & $-0.021 \%$ & -0.690 \\
\hline 6 & $-0.022 \%$ & -1.457 & $-0.023 \%$ & -1.362 & $-0.021 \%$ & -0.793 \\
\hline 7 & $-0.003 \%$ & -0.149 & $0.011 \%$ & 0.393 & $-0.019 \%$ & -0.669 \\
\hline 8 & $-0.002 \%$ & -0.126 & $-0.001 \%$ & -0.027 & $-0.005 \%$ & -0.134 \\
\hline 9 & $0.019 \%$ & 0.878 & $0.035 \%$ & 1.105 & $0.001 \%$ & 0.033 \\
\hline 10 & $-0.004 \%$ & -0.166 & $0.024 \%$ & 0.530 & $-0.038 \%$ & -1.476 \\
\hline-10 to -1 & $0.077 \%$ & 0.633 & $0.171 \%$ & 0.932 & -0.031 & -0.201 \\
\hline 0 to 10 & $0.256 \%$ & $1.718 *$ & $0.314 \%$ & $2.149 * *$ & $0.001 \%$ & 0.044 \\
\hline
\end{tabular}

Table presents the daily average abnormal turnover (AATO) surrounding the total sample of bank loan announcements, the initial sample of bank loan announcements and the subsequent sample of bank loan announcements. AATO is calculated as outlined in equation (11). Cumulative average abnormal turnover is presented for the -10 to -1 and 0 to 10 day event window and calculated as the sum of the AATO of each day during the event window outlined in equation (12). Student t-statistics are presented to show if the AATO is significantly different from zero. Event Day ' 0 ' represents the day of the bank loan announcement. Two tailed tests of significance are reported as follows $* * *$ less than $0.01 * *$ less than 0.05 and * less than 0.10 . 
Table 9 Average abnormal spread surrounding bank loan announcements.

\begin{tabular}{|c|c|c|c|c|c|c|}
\hline & Total sample & $(n=362)$ & Initial sampl & $(n=193)$ & Subsequent se & mple $(n=169)$ \\
\hline Event Day & AASPREAD & t-stat & AASPREAD & t-stat & AASPREAD & t-stat \\
\hline-10 & $-0.312 \%$ & -1.624 & $-0.716 \%$ & $-2.313^{* *}$ & $0.149 \%$ & 0.719 \\
\hline-9 & $0.205 \%$ & 0.716 & $0.440 \%$ & 0.862 & $-0.063 \%$ & -0.325 \\
\hline-8 & $-0.053 \%$ & -0.219 & $-0.141 \%$ & -0.347 & $0.047 \%$ & 0.200 \\
\hline-7 & $0.195 \%$ & 0.808 & $0.276 \%$ & 0.674 & $0.102 \%$ & 0.461 \\
\hline-6 & $0.100 \%$ & 0.408 & $0.277 \%$ & 0.737 & $-0.103 \%$ & -0.343 \\
\hline-5 & $-0.011 \%$ & -0.049 & $0.032 \%$ & 0.085 & $-0.060 \%$ & -0.307 \\
\hline-4 & $-0.124 \%$ & -0.453 & $-0.219 \%$ & -0.449 & $-0.016 \%$ & -0.085 \\
\hline-3 & $0.223 \%$ & 0.736 & $0.312 \%$ & 0.589 & $0.121 \%$ & 0.509 \\
\hline-2 & $0.126 \%$ & 0.504 & $0.230 \%$ & 0.556 & $0.007 \%$ & 0.027 \\
\hline-1 & $0.010 \%$ & 0.040 & $0.188 \%$ & 0.465 & $-0.194 \%$ & -0.864 \\
\hline 0 & $-0.136 \%$ & -0.613 & $-0.146 \%$ & -0.381 & $-0.124 \%$ & -0.686 \\
\hline 1 & $-0.524 \%$ & $-2.495^{* *}$ & $-0.546 \%$ & $-1.652^{*}$ & $-0.499 \%$ & $-2.030 * *$ \\
\hline 2 & $-0.244 \%$ & -1.123 & $-0.240 \%$ & -0.650 & $-0.249 \%$ & -1.245 \\
\hline 3 & $-0.188 \%$ & -0.720 & $0.101 \%$ & 0.227 & $-0.518 \%$ & $-2.298 * *$ \\
\hline 4 & $-0.205 \%$ & -0.696 & $-0.206 \%$ & -0.422 & $-0.205 \%$ & -0.683 \\
\hline 5 & $0.027 \%$ & 0.101 & $0.236 \%$ & 0.516 & $-0.212 \%$ & -0.887 \\
\hline 6 & $-0.572 \%$ & $-2.137 * *$ & $-0.377 \%$ & -1.178 & $-0.795 \%$ & $-1.797^{*}$ \\
\hline 7 & $-0.605 \%$ & $-2.403 * *$ & $-0.360 \%$ & -1.205 & $-0.884 \%$ & $-2.118 * *$ \\
\hline 8 & $-0.460 \%$ & $-1.938 *$ & $-0.170 \%$ & -0.481 & $-0.793 \%$ & $-2.552 * *$ \\
\hline 9 & $-0.182 \%$ & -0.791 & $-0.150 \%$ & -0.374 & $-0.220 \%$ & -1.155 \\
\hline 10 & $-0.211 \%$ & -0.877 & $-0.204 \%$ & -0.480 & $-0.219 \%$ & -1.244 \\
\hline-10 to -1 & $0.358 \%$ & 0.197 & $0.679 \%$ & 0.210 & $-0.010 \%$ & -0.008 \\
\hline 1 to 10 & $-3.165 \%$ & $-1.915^{*}$ & $-1.914 \%$ & -0.693 & $-4.593 \%$ & $-2.854 * * *$ \\
\hline
\end{tabular}

Table presents the average abnormal spread surrounding the total sample of bank loan announcements, the initial sample of bank loan announcements, and the sample of subsequent loan announcements. Abnormal spread is calculated as outlined in equation (7). Cumulative average abnormal spread is presented for the event window -10 to -1 and 1 to 10 and calculated as outlined in equation (8). Student t-statistics are presented to show if the AASPREAD is significantly different from zero. Event Day ' 0 ' represents the day of the bank loan announcement. Two tailed tests of significance are reported as follows *** less than $0.01 * *$ less than 0.05 and * less than 0.10 . 
Table 10 Determinants of abnormal turnover and abnormal spread

\begin{tabular}{|c|c|c|c|c|c|c|}
\hline & \multicolumn{3}{|c|}{ Panel A: Abnormal Turnover -10 to 10} & \multicolumn{3}{|c|}{ Panel B: Abnormal Spread -10 to 10} \\
\hline & Coeff & t-stat & p-value & Coeff & t-stat & p-value \\
\hline (Constant) & -.007 & -.283 & .777 & -.545 & $-2.305 * *$ & .022 \\
\hline Initial & .002 & .710 & .478 & .019 & .700 & .485 \\
\hline FirstAnn & .008 & $2.644 * * *$ & .009 & -.045 & -1.559 & .120 \\
\hline LnAmount & .002 & 1.163 & .246 & -.010 & -.713 & .476 \\
\hline Lenders & .001 & .902 & .368 & -.031 & $-2.168 * *$ & .031 \\
\hline Hedge & .000 & .137 & .891 & .005 & .164 & .870 \\
\hline BankEquity & -.008 & $-2.313 * *$ & .021 & .016 & .489 & .625 \\
\hline EquityRaise & .013 & $2.809 * * *$ & .005 & .034 & .766 & .444 \\
\hline LnMCAP & 0.00 & .043 & .966 & .033 & $2.567 * *$ & .011 \\
\hline Loss & .004 & 1.286 & .199 & -.056 & $-1.835^{*}$ & .067 \\
\hline NumAnalyst & .000 & -.764 & .445 & -.002 & -.440 & .660 \\
\hline F-stat & 2.804 & & $0.002 * * *$ & 2.517 & & $.006 * * *$ \\
\hline Adjusted R2 & .046 & & & .042 & & \\
\hline $\mathbf{N}$ & 370 & & & 345 & & \\
\hline
\end{tabular}

Table Panel A presents an Ordinary Least Squares regression on the determinants of the cumulative average abnormal turnover over the -10 to 10 day event window. Panel B presents an Ordinary Least Squares regression on the determinants of the cumulative average abnormal spread over the -10 to 10 day event window. Regression variables are defined as: Initial represents a binary variable capturing if the loan is an initial loan. FirstAnn is a binary variable equal to one if the announcement is the first in a sequence of announcements. LnAmount is calculated as the dollar amount of borrowed funds scaled by the borrowing firm's total assets in the period prior to the loan announcement. Lenders is the number of lenders mentioned in the bank loan announcement. Hedge is a binary variable equal to 1 if it is disclosed within the bank loan announcement that the bank requires the borrowing to hedge its commodity or foreign exchange exposure before a loan agreement can be completed. BankEquity is a binary variable equal to 1 if it is disclosed within the bank loan announcement that the bank owns shares, warrants or options of the borrowing firm. EquityRaise is a binary variable equal to 1 if it is disclosed within the bank loan announcement that the bank requires the borrowing firm to raise further equity before a loan agreement can be completed. LnMCap is the natural logarithm of the firm's market capitalisation 15 days before the bank loan announcement. Loss is a binary variable equal to 1 if the firm reported a net profit after tax of less than zero in the annual report prior to the bank loan announcement. NumAnalyst is the number of analysts following firm $i$ on the announcement date. p-values are provided based on two-tailed tests of significance 
Table 11 Cumulative average abnormal returns for loans issued by an industry specialist or non-specialist

\begin{tabular}{lrrrrrrr}
\hline \multicolumn{2}{c}{$\begin{array}{l}\text { Macquarie Bank } \\
\text { (n=69) }\end{array}$} & \multicolumn{2}{c}{$\begin{array}{l}\text { Non Macquarie Bank } \\
\text { (n=327) }\end{array}$} & Difference & & \\
\hline Event Day & CAAR & t-stat & CAAR & t-stat & Mean difference & t-stat & p-value \\
$\mathbf{- 5}$ to $\mathbf{5}$ & $5.053 \%$ & $\mathbf{3 . 0 6 3 * * *}$ & $1.89 \%$ & $\mathbf{2 . 1 6 7 * *}$ & $3.167 \%$ & $\mathbf{1 . 7 4 5 * *}$ & $\mathbf{0 . 0 4 2}$ \\
& & & & & & & \\
$\mathbf{- 3}$ to $\mathbf{3}$ & $4.125 \%$ & $\mathbf{2 . 8 8 4 * * *}$ & $2.45 \%$ & $\mathbf{3 . 5 9 9 * * *}$ & $1.677 \%$ & 1.071 & 0.143 \\
$\mathbf{- 1}$ to $\mathbf{1}$ & $2.564 \%$ & $\mathbf{2 . 5 1 8 * *}$ & $2.32 \%$ & $\mathbf{5 . 3 3 6 * * *}$ & $0.242 \%$ & .219 & 0.414 \\
\hline
\end{tabular}

Table presents the cumulative average abnormal return (CAAR) surrounding loans issued by Macquarie Bank, and loans issued by non-industry specialist lenders. $t$-statistics test if the CAAR is significantly different from zero. The mean difference shows the difference between the two sample CAARs. $t$-statistics are provided to test if the two sample means are significantly different. p-values are provided based on a one-tailed test of significance. 
Table 12 Determinants of market reaction around bank loan announcements testing for industry specialisation

\begin{tabular}{|c|c|c|c|c|c|c|c|c|c|c|}
\hline & Predicted & \multicolumn{3}{|c|}{ Panel A: 0 to +1 } & \multicolumn{3}{|c|}{ Panel B: -5 to +5} & \multicolumn{3}{|c|}{ Panel C: -10 to +10} \\
\hline (Constant) & & $\begin{array}{l}\text { Coeff } \\
.002\end{array}$ & $\begin{array}{l}\text { t-stat } \\
.029\end{array}$ & $\begin{array}{l}\text { p-value } \\
.977\end{array}$ & $\begin{array}{l}\text { Coeff } \\
.024\end{array}$ & $\begin{array}{l}\text { t-stat } \\
.190\end{array}$ & $\begin{array}{l}\text { p-value } \\
.849\end{array}$ & $\begin{array}{l}\text { Coeff } \\
-.022\end{array}$ & $\begin{array}{l}\text { t-stat } \\
-.122\end{array}$ & $\begin{array}{l}\text { p-value } \\
.903\end{array}$ \\
\hline Macquarie & + & -.006 & -.539 & .590 & .032 & $1.636^{*}$ & $0.100 *$ & .078 & $2.804 * * *$ & .005 \\
\hline Initial & + & .005 & .600 & .549 & -.013 & -.868 & .386 & -.012 & -.587 & .558 \\
\hline FirstAnn & + & .028 & $3.175 * * *$ & .002 & .027 & $1.732 *$ & .084 & .048 & $2.186 * *$ & .029 \\
\hline LnAmount & + & .018 & $4.363 * * *$ & .000 & .017 & $2.313 * *$ & .021 & .009 & .879 & .380 \\
\hline Lenders & - & -.001 & -.343 & .732 & .011 & 1.508 & .132 & .003 & .329 & .742 \\
\hline Hedge & $?$ & -.014 & -1.400 & .162 & -.013 & -.722 & .471 & -.038 & -1.557 & .120 \\
\hline BankEquity & + & .018 & $1.697 *$ & .091 & .016 & .895 & .371 & .022 & .854 & .393 \\
\hline EquityRaise & - & -.007 & -.517 & .606 & .061 & $2.470 * *$ & .014 & .064 & $1.811 *$ & .071 \\
\hline LnMCAP & - & .001 & .342 & .732 & -.002 & -.240 & .810 & -.001 & -.104 & .917 \\
\hline Loss & + & .001 & .083 & .934 & .025 & 1.498 & .135 & .036 & 1.544 & .123 \\
\hline NumAnalyst & - & -.001 & -.372 & .710 & -.006 & $-2.064 * *$ & .040 & -.009 & $-2.382 * *$ & .018 \\
\hline $\begin{array}{l}\text { F-stat } \\
\text { Adjusted R2 } \\
\text { N }\end{array}$ & & $\begin{array}{l}3.840 \\
.077 \\
374\end{array}$ & & $0.000 * * *$ & $\begin{array}{l}3.160 \\
.060 \\
374\end{array}$ & & $.000 * * *$ & $\begin{array}{l}3.072 \\
.057 \\
374 \\
\end{array}$ & & $.001^{* * * *}$ \\
\hline
\end{tabular}

Table 1 presents Ordinary Least Squares regressions on the determinants of the cumulative average abnormal return around the release of a bank loan announcement. Panel A reports results over the event windows 0 to 1, Panel B reports results over the event window -5 to 5 and Panel C reports results over the event window - 10 to 10 .

Regression variables are defined as: Macquarie represents a binary variable equal to one if the loan is issued by industry leader Macquarie Bank Initial represents a binary variable capturing if the loan is an initial loan. FirstAnn is a binary variable equal to one if the announcement is the first in a sequence of announcements. LnAmount is

calculated as the dollar amount of borrowed funds scaled by the borrowing firm's total assets in the period prior to the loan announcement. Lenders is the number of lenders mentioned in the bank loan announcement. Hedge is a binary variable equal to 1 if it is disclosed within the bank loan announcement that the bank requires the borrowing to hedge its commodity or foreign exchange exposure before a loan agreement can be completed. BankEquity is a binary variable equal to 1 if it is disclosed within the bank loan announcement that the bank owns shares, warrants or options of the borrowing firm. EquityRaise is a binary variable equal to 1 if it is disclosed within the bank loan announcement that the bank requires the borrowing firm to raise further equity before a loan agreement can be completed. LnMCap is the natural logarithm of the firm's market capitalisation 15 days before the bank loan announcement. Loss is a binary variable equal to 1 if the firm reported a net profit after tax of less than zero in the annual report prior to the bank loan announcement. NumAnalyst is the number of analysts following firm $i$ on the announcement date. p-values are provided based on two-tailed tests of significance. 
Figure 1 Daily average abnormal returns (AAR) over the -10 to 10 day event

window.

Panel A: Daily average abnormal returns over the -10 to 10 day event window for the total sample of bank loan announcements.

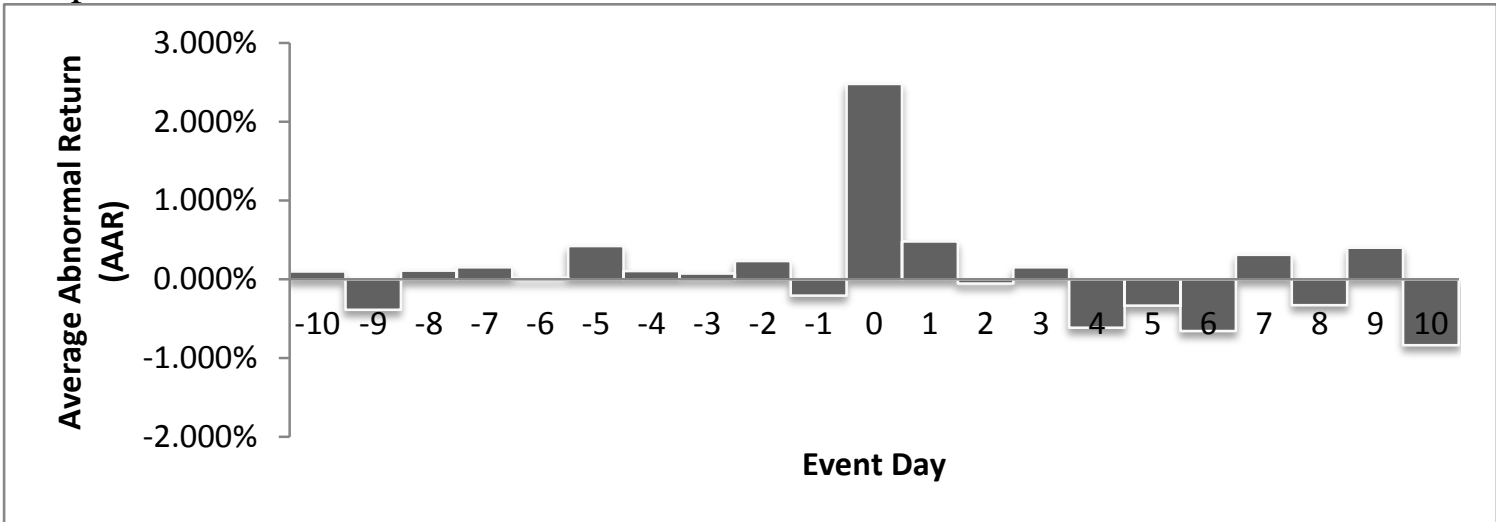

Panel B: Daily average abnormal returns over the -10 to 10 day event window for the initial bank loan sample of announcements.

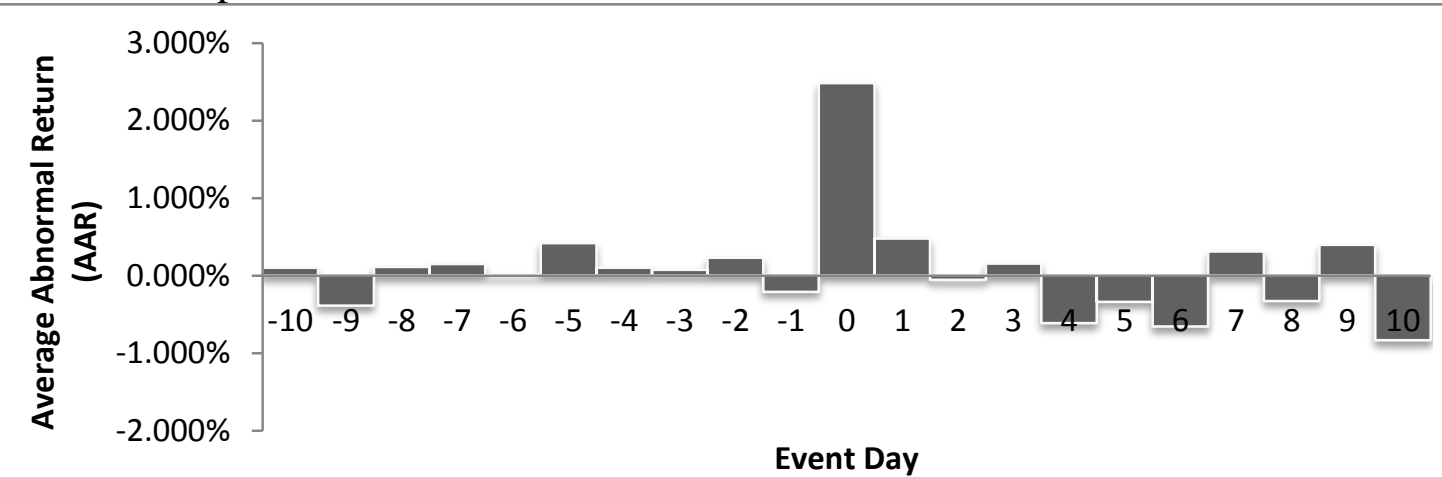

Panel C: Daily average abnormal returns over the -10 to 10 day event window for the subsequent bank loan sample of announcements.

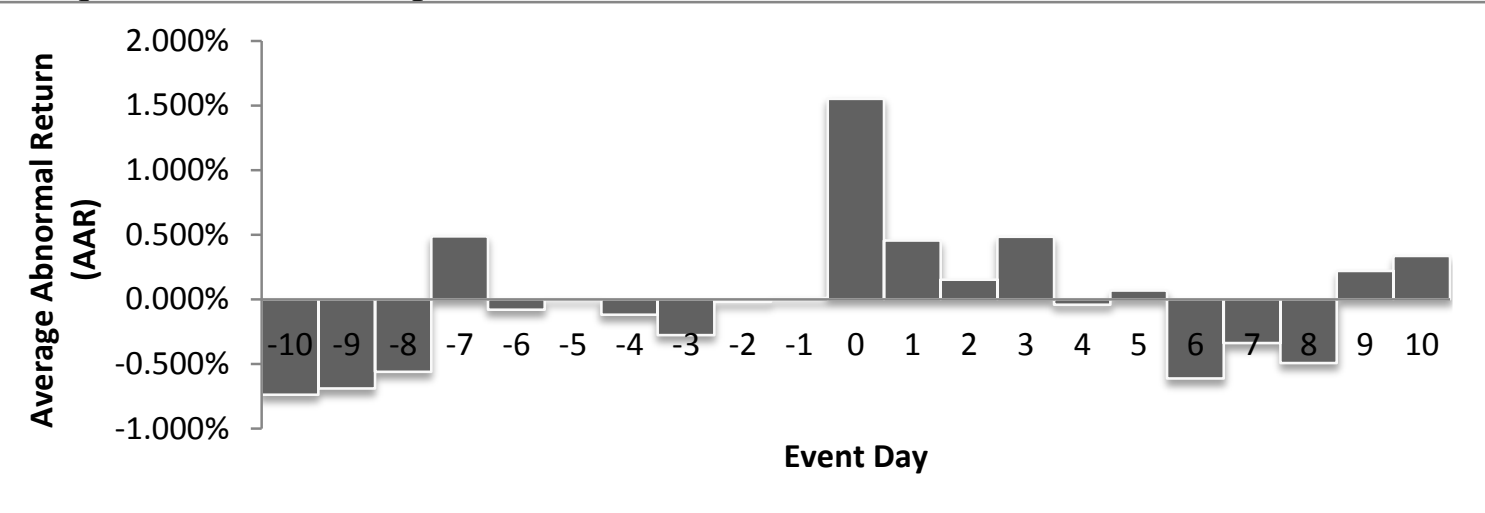

Figure 1, Panel A shows the average abnormal return for each event day in the -10 to 10 day event window, using the full sample of bank loan announcements. Panel B shows the average abnormal return for each event day in the -10 to 10 day event window, surrounding the sample of initial bank loan announcements. Panel C shows the average abnormal return for each event day in the -10 to 10 day event window, surrounding the sample of subsequent bank loan announcements. Event day 0 represents the date of the bank loan announcement. 
Figure 2 Cumulative average abnormal returns (CAAR) over the -5 to 5 day

\section{event window.}

Panel A: Cumulative average abnormal returns over the -5 to 5 day event window for the total sample of bank loan announcements.

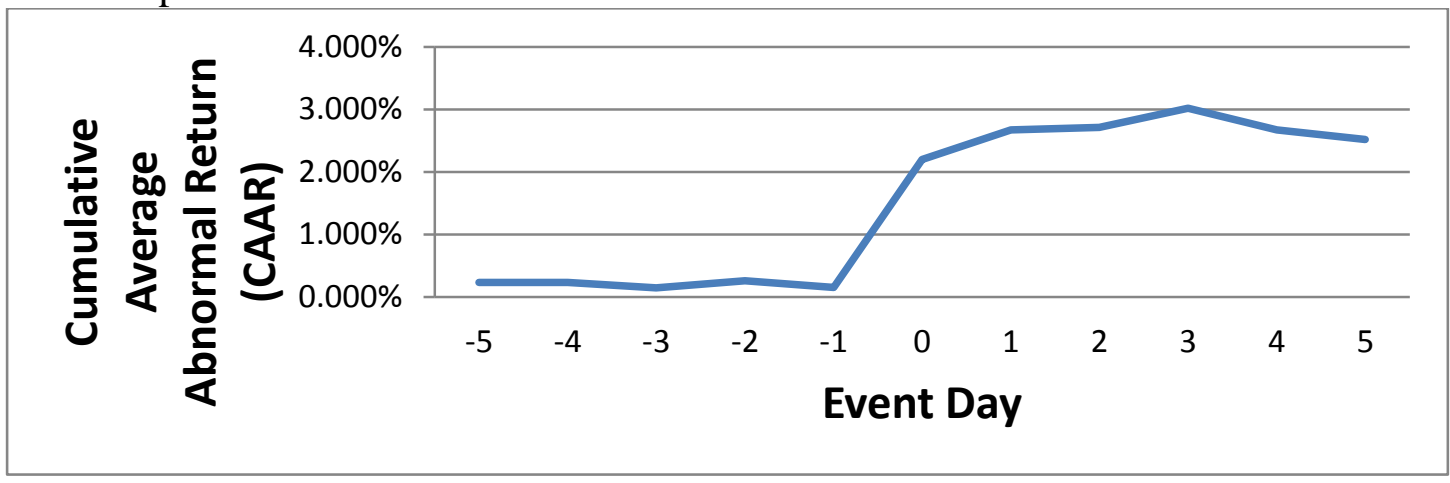

Panel B: Cumulative average abnormal returns over the -5 to 5 day event window for the initial bank loan sample of announcements.

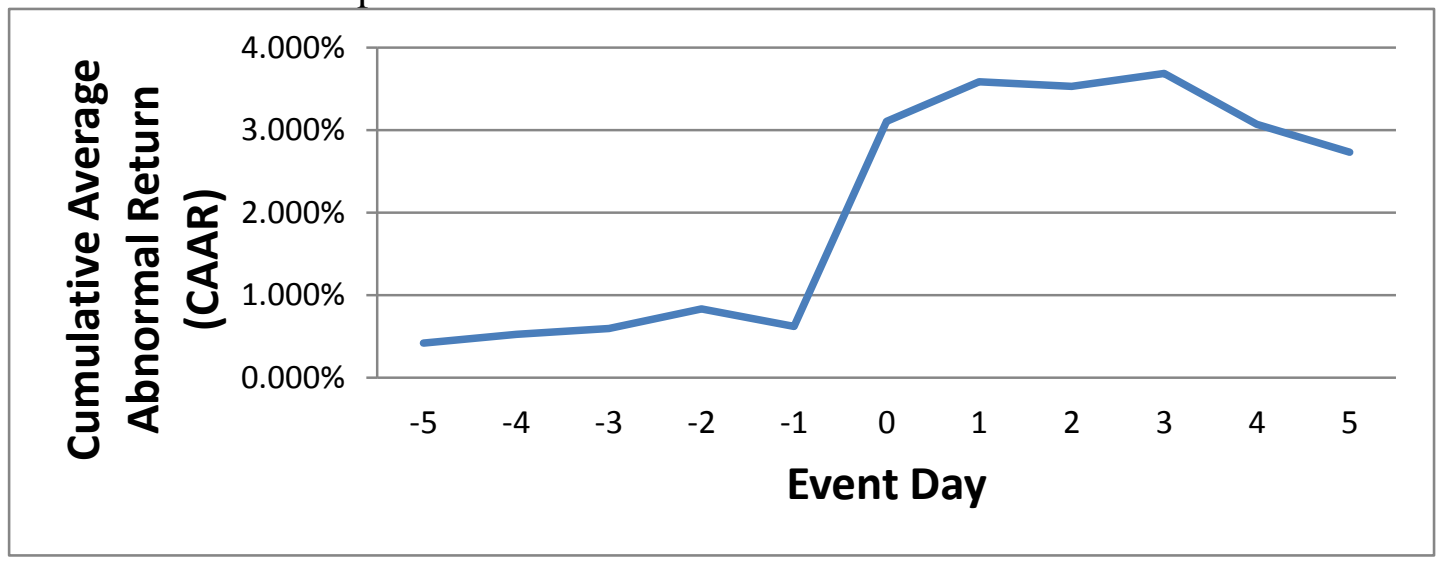

Panel C: Cumulative average abnormal returns over the -5 to 5 day event window for the subsequent bank loan sample of announcements.

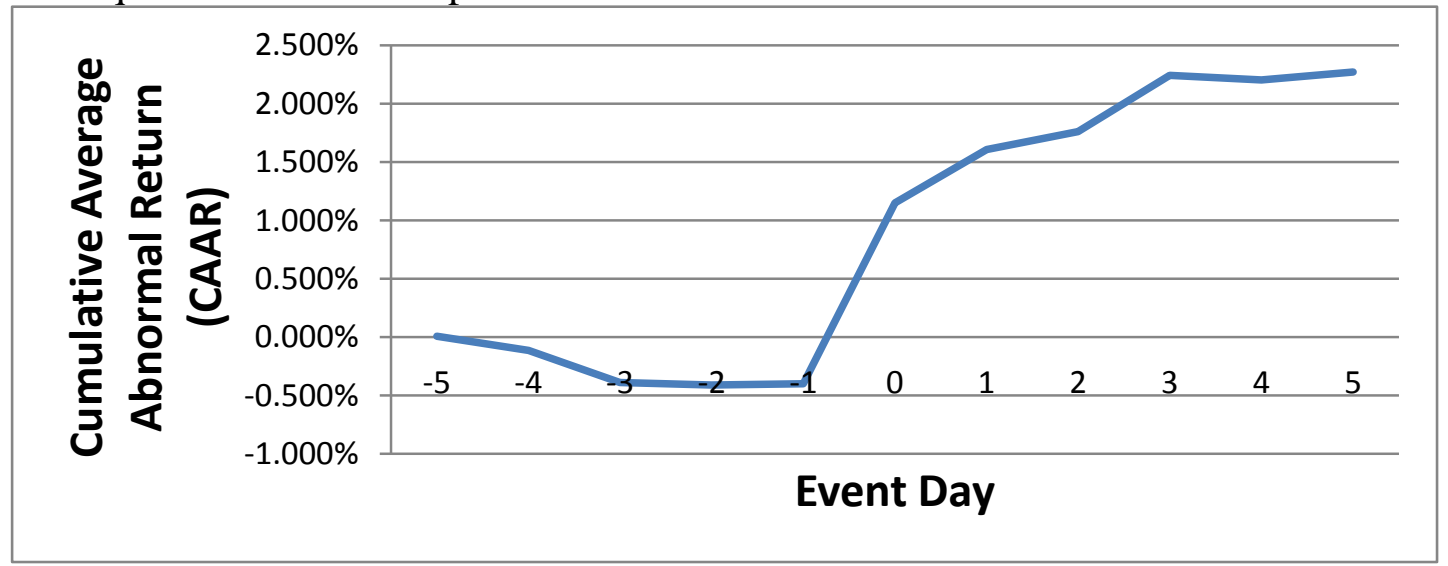

Figure 2 Panel A shows the cumulative average abnormal return over the -5 to 5 day event window, using the full sample of bank loan announcements. Panel B shows the cumulative average abnormal return over the -5 to 5 day event window, using the sample of initial bank loan announcements. Panel $\mathrm{C}$ shows the cumulative average abnormal return over the -5 to 5 day event window, using the sample of subsequent bank loan announcements. Event day 0 represents the date of the bank loan announcement. 
Figure 3 Average abnormal turnover (AATO) over the -10 to 10 event window

Panel A: Average abnormal turnover over the -10 to 10 event window surrounding the total sample of bank loan announcements.

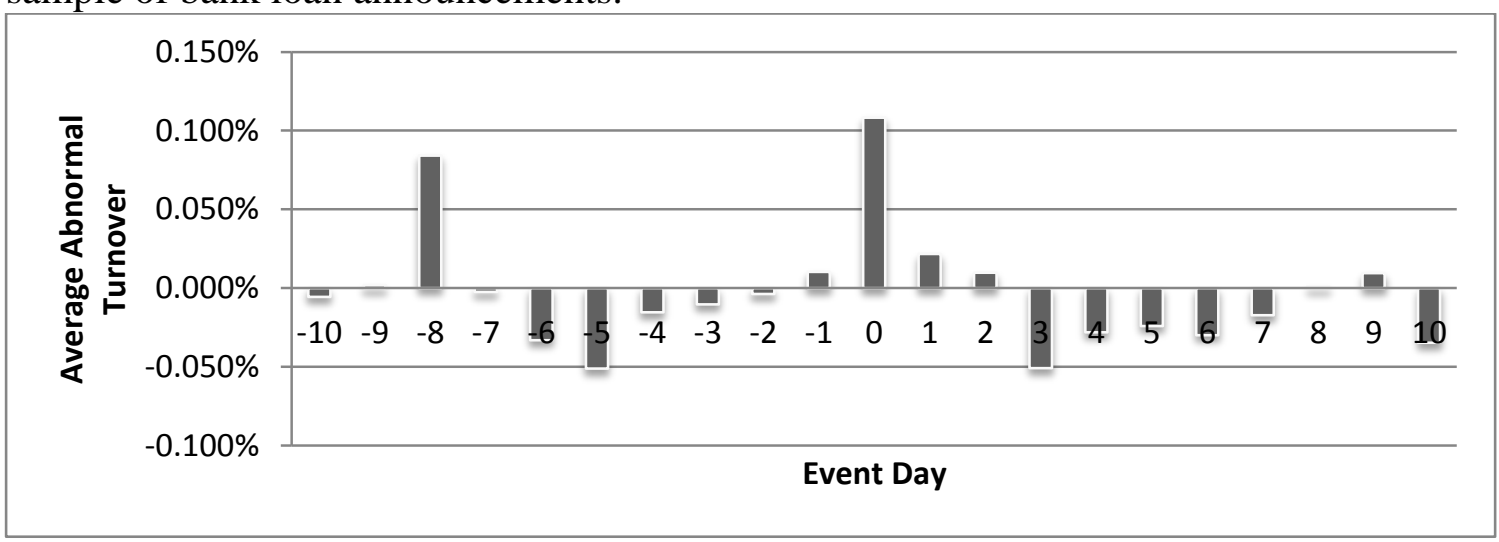

Panel B: Average abnormal turnover over the -10 to 10 event window surrounding the sample of initial bank loan announcements.

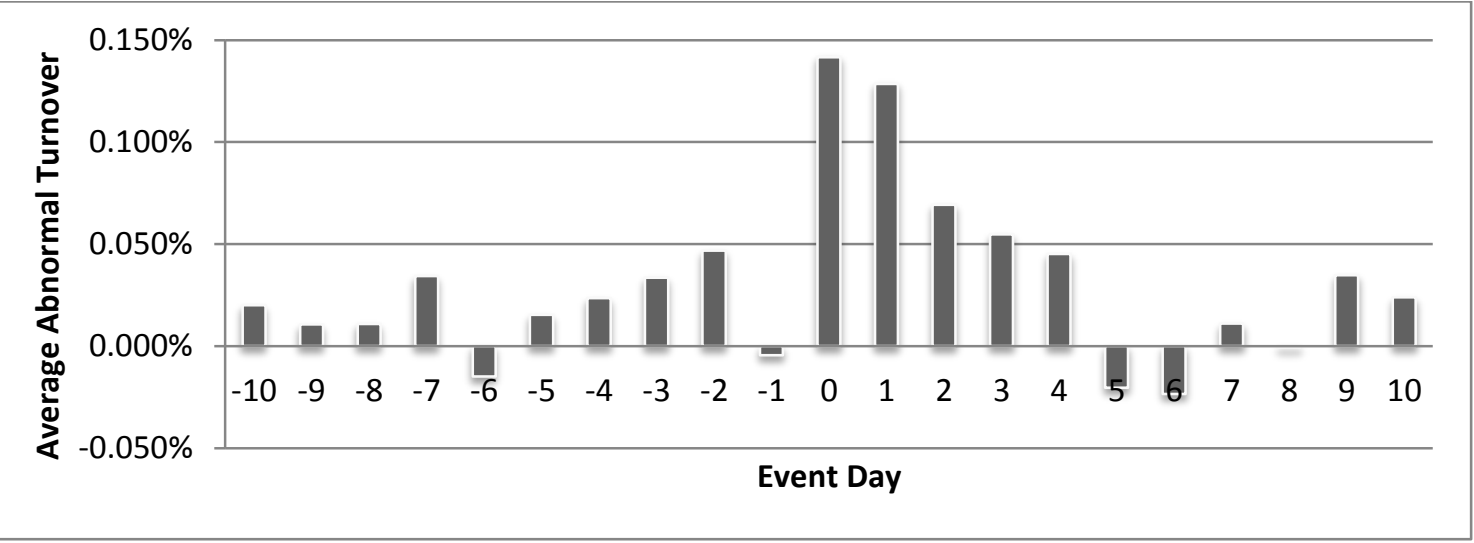

Panel C: Average abnormal turnover over the -10 to 10 event window surrounding the sample of subsequent bank loan announcements.

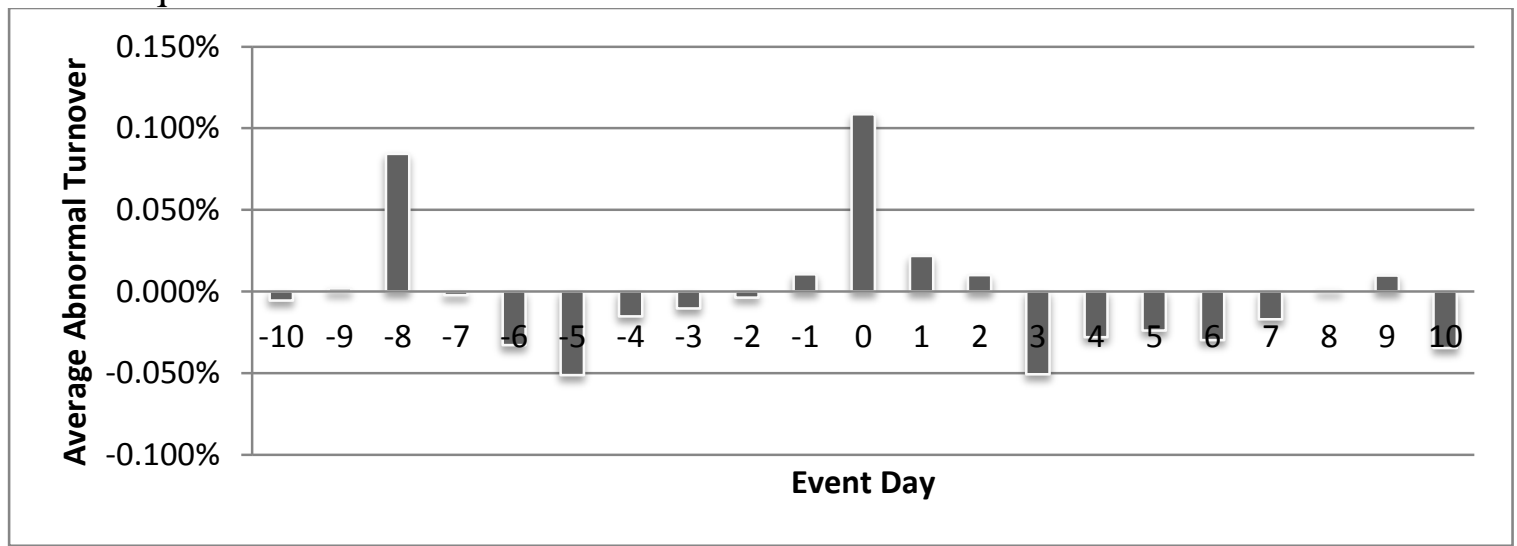

Figure 3 Panel A shows the cumulative average abnormal return over the -5 to 5 day event window; using the full sample of bank loan announcements. Panel B shows the cumulative average abnormal return over the -5 to 5 day event window, using the sample of initial bank loan announcements. Panel $\mathrm{C}$ shows the cumulative average abnormal return over the -5 to 5 day event window, using the sample of subsequent bank loan announcements. Event day 0 represents the date of the bank loan announcement. 
Panel A: Average abnormal spread over the -10 to 10 event window surrounding the total sample of bank loan announcements.

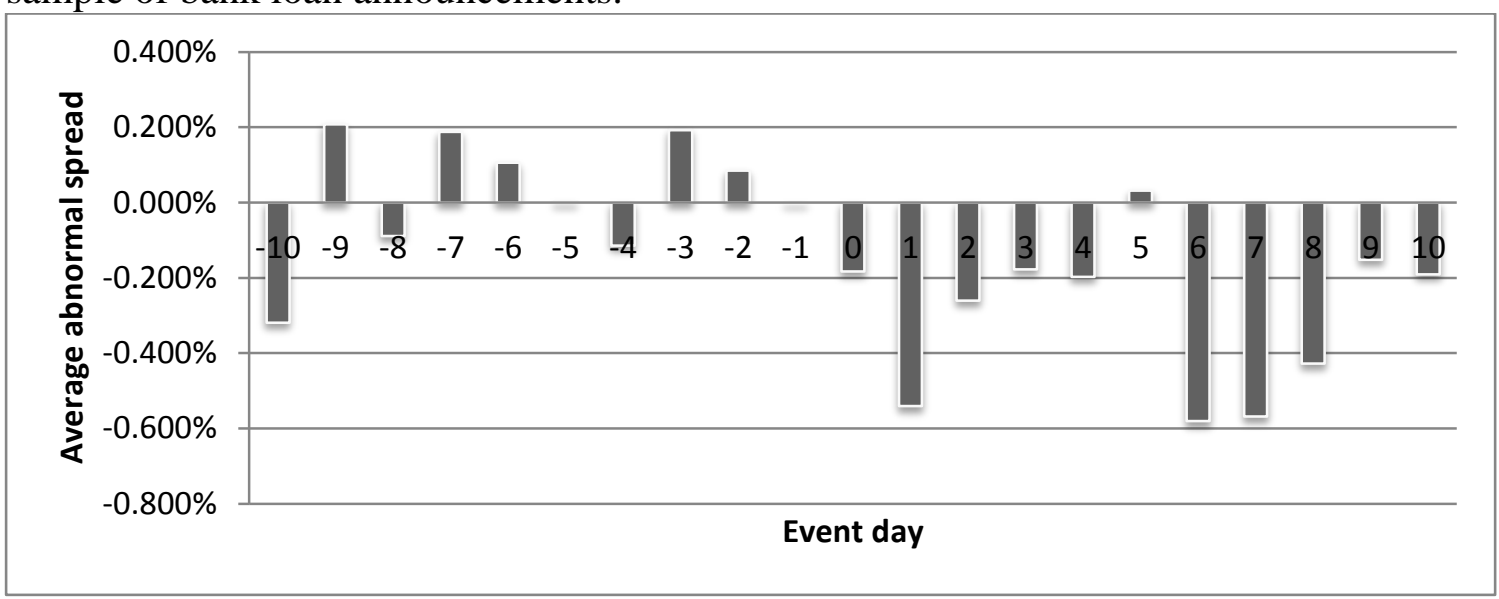

Panel B: Average abnormal spread over the -10 to 10 event window surrounding the initial bank loan sample of announcements.

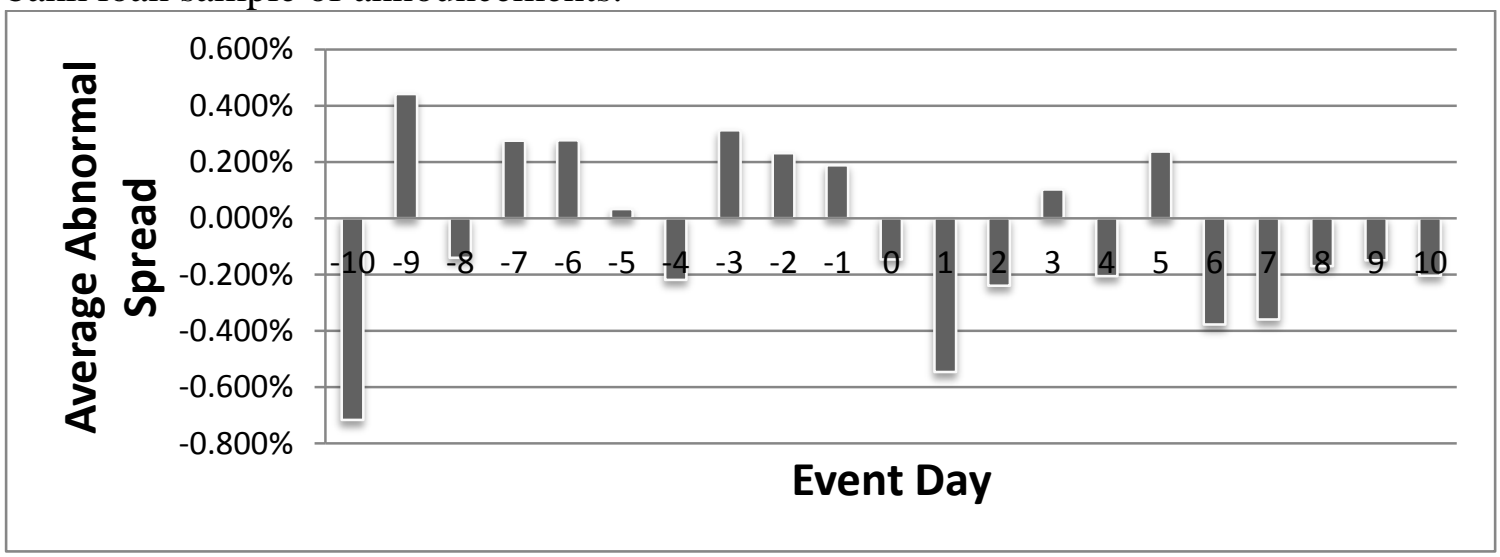

Panel C: Average abnormal spread over the -10 to 10 event window surrounding the sample of subsequent bank loan announcements.

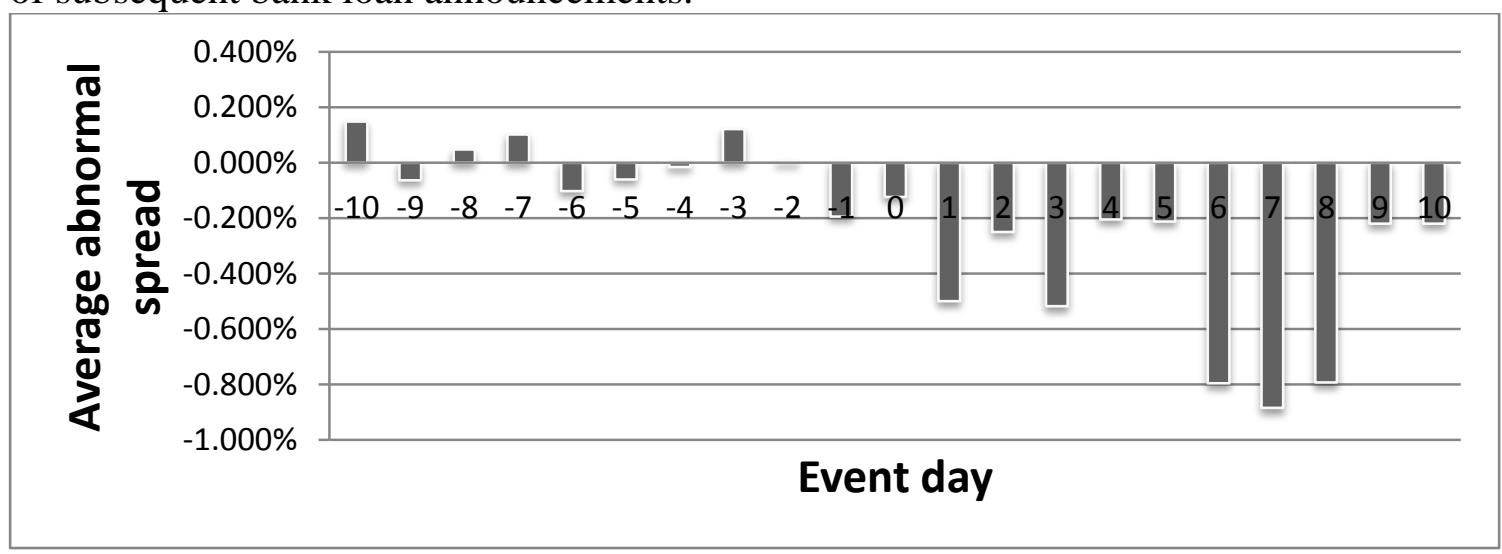

Figure 4 Panel A presents the average abnormal spread surrounding the total sample of bank loan announcements. Panel B presents the average abnormal spread surrounding the sample of initial bank loan announcements. Panel C presents average abnormal spread surrounding the sample of subsequent bank loan announcements. Abnormal spread is calculated as in equation (6). Event day ' 0 ' represents the date of the bank loan announcement. 


\section{References}

Acharya, V.V., Hasan, I., Saunders, A., 2006. Should Banks Be Diversified? Evidence from Individual Bank Loan Portfolios. The Journal of Business 79, 1355-1412

Aintablian, S., Roberts, G.S., 2000. A note on market response to corporate loan announcements in Canada. Journal of Banking \& Finance 24, 381-393

Almazan, A., 2002. A model of competition in banking: Bank capital vs expertise. Journal of Financial Intermediation 11, 87-121

ASX, 2013. Chapter 3 Continuous Disclosure

ASX, 2014. Guidance Note 8. ASX Listing Rules

Bernanke, B.S., 1983. Nonmonetary Effects of the Financial Crisis in the Propagation of the Great Depression. The American economic review 73, 257-276

Best, R., Zhang, H., 1993. Alternative Information Sources and the Information Content of Bank Loans. The Journal of Finance 48, 1507-1522

Billett, M.T., Flannery, M.J., Garfinkel, J.A., 1995. The Effect of Lender Identity on a Borrowing Firm's Equity Return. The Journal of Finance 50, 699-718

Billett, M.T., Flannery, M.J., Garfinkel, J.A., 2006. Are bank loans special? Evidence on the postannouncement performance of bank borrowers. Journal of Financial and Quantitative Analysis 41, 733-751

Bird, R., Grosse, M., Yeung, D., 2013. The market response to exploration, resource and reserve announcements by mining companies: Australian data. Australian Journal of Management 38, 311-331

Black, F., 1975. Bank funds management in an efficient market. Journal of Financial Economics 2, 323-339

Bolton, P., Freixas, X., 2000. Equity, bonds, and bank debt: Capital structure and financial market equilibrium under asymmetric information. Journal of Political Economy 108, 324-351

Bolton, P., Scharfstein, D.S., 1996. Optimal debt structure and the number of creditors. Journal of Political Economy, 1-25

Bonaccorsi di Patti, E., Dell'Ariccia, G., 2004. Bank Competition and Firm Creation. Journal of Money, Credit, and Banking 36, 225-251

Boone, J.P., 1998. Oil and gas reserve value disclosures and bid-ask spreads. Journal of Accounting and Public Policy 17, 55-84

Booth, J.R., Chua, L., 1996. Ownership dispersion, costly information, and IPO underpricing. Journal of Financial Economics 41, 291-310

Boscaljon, B., Ho, C.-C., 2005. Information content of bank loan announcements to Asian corporations during periods of economic uncertainty. Journal of Banking \& Finance 29, 369389

Boyd, J.H., Prescott, E.C., 1986. Financial intermediary-coalitions. Journal of Economic Theory 38, 211-232

Brennan, M.J., Schwartz, E.S., 1985. Evaluating natural resource investments. Journal of business, 135-157

Brown, P., Feigin, A., Ferguson, A., 2013. Market reactions to the reports of a star resource analyst. Australian Journal of Management

Brown, P., Ferguson, A., Stone, K., 2008. Share purchase plans in Australia: Issuer characteristics and valuation implications. Australian Journal of Management 33, 307-332

Brown, S.J., Warner, J.B., 1985. Using daily stock returns: The case of event studies. Journal of financial economics 14, 3-31

Bushman, R.M., Wittenberg-Moerman, R., 2012. The role of bank reputation in "certifying" future performance implications of borrowers' accounting numbers. Journal of Accounting Research $50,883-930$

Campbell, C.J., Wasley, C.E., 1993. Measuring security price performance using daily NASDAQ returns. Journal of Financial Economics 33, 73-92

Campbell, T.S., 1979. Optimal investment financing decisions and the value of confidentiality. Journal of Financial and Quantitative Analysis, 913-924 
Campbell, T.S., Kracaw, W.A., 1980. Information Production, Market Signalling, and the Theory of Financial Intermediation. The Journal of Finance 35, 863-882

Carey, M., Post, M., Sharpe, S.A., 1998. Does Corporate Lending by Banks and Finance Companies Differ? Evidence on Specialization in Private Debt Contracting. The Journal of Finance 53, 845-878

Carter, R., Manaster, S., 1990. Initial public offerings and underwriter reputation. The Journal of Finance 45, 1045-1067

Corrado, C.J., 2011. Event studies: a methodology review. Accounting \& Finance 51, 207-234

Corrado, C.J., Truong, C., 2008. Conducting event studies with Asia-Pacific security market data. Pacific-Basin finance journal 16, 493-521

Craswell, A.T., Francis, J.R., Taylor, S.L., 1995. Auditor brand name reputations and industry specializations. Journal of Accounting and Economics 20, 297-322

Datta, S., Iskandar-Datta, M., Patel, A., 1999. Bank monitoring and the pricing of corporate public debt. Journal of Financial Economics 51, 435-449

DeAngelo, L.E., 1981. Auditor size and audit quality. Journal of Accounting and Economics 3, 183199

Devos, E., Dhillon, U., Jagannathan, M., Krishnamurthy, S., 2012. Why are firms unlevered? Journal of Corporate Finance 18, 664-682

Dhaliwal, D.S., Khurana, I.K., Pereira, R., 2011. Firm Disclosure Policy and the Choice Between Private and Public Debt. Contemporary Accounting Research 28, 293-330

Diamond, D.W., 1984. Financial Intermediation and Delegated Monitoring. The Review of Economic Studies 51, 393-414

Diamond, D.W., 1989. Reputation Acquisition in Debt Markets. Journal of Political Economy 97, 828

Diamond, D.W., 1991. Monitoring and reputation: The choice between bank loans and directly placed debt. Journal of Political Economy, 689-721

Diamond, D.W., Verrecchia, R.E., 1991. Disclosure, liquidity, and the cost of capital. The Journal of Finance 46, 1325-1359

Easley, D., Kiefer, N.M., O'hara, M., Paperman, J.B., 1996. Liquidity, information, and infrequently traded stocks. The Journal of Finance 51, 1405-1436

Eckbo, B.E., 1986. Valuation effects of corporate debt offerings. Journal of Financial economics 15, 119-151

Fama, E.F., 1985. What's different about banks? Journal of Monetary Economics 15, 29-39

Fang, L.H., 2005. Investment bank reputation and the price and quality of underwriting services. The Journal of Finance 60, 2729-2761

Faulkender, M., Petersen, M.A., 2006. Does the source of capital affect capital structure? Review of financial studies $19,45-79$

Ferguson, A., Clinch, G., Kean, S., 2011a. Predicting the Failure of Developmental Gold Mining Projects. Australian Accounting Review 21, 44-53

Ferguson, A., Crockett, A., 2003. Information transfer and press coverage: The case of the Gawler Craton gold boom. Pacific-Basin Finance Journal 11, 101-120

Ferguson, A., Francis, J.R., Stokes, D.J., 2003. The effects of firm-wide and office-level industry expertise on audit pricing. The Accounting Review 78, 429-448

Ferguson, A., Grosse, M., Kean, S., Scott, T., 2011b. Your Governance or Mine? Australian Accounting Review 21, 406-417

Ferguson, A., Pundrich, G., 2013. Does Non-GAAP Expertise Matter to Investors? Available at SSRN 2298534

Ferguson, A., Pundrich, G., Raftery, A., 2012. Auditor Industry Specialisation and Market Segmentation: Evidence from the Perth Mining Cash-Box Market. Available at SSRN 1974282

Ferguson, A., Stokes, D., 2002. Brand Name Audit Pricing, Industry Specialization, and Leadership Premiums post - Big 8 and Big 6 Mergers*. Contemporary Accounting Research 19, 77-110

Fery, J., Gasbarro, D., Woodliff, D.R., Zumwalt, J.K., 2003. Market reaction to published and nonpublished corporate loan announcements. The Quarterly Review of Economics and Finance $43,1-10$ 
Fields, L.P., Fraser, D.R., Berry, T.L., Byers, S., 2006. Do bank loan relationships still matter? Journal of Money, Credit, and Banking 38, 1195-1209

Flannery, M.J., 1986. Asymmetric Information and Risky Debt Maturity Choice. Journal of Finance, 19-37

Gonzalez, L., 2011. Dogs that Bark: Why are Bank Loan Announcements Newsworthy? Global Economy and Finance Journal 4, 62-79

Gorton, G., Kahn, J.A., 1993. The design of bank loan contracts, collateral, and renegotiation. National Bureau of Economic Research

Hauswald, R., Marquez, R., 2006. Competition and strategic information acquisition in credit markets. Review of financial studies 19, 967-1000

Hotelling, H., 1931. The economics of exhaustible resources. The Journal of Political Economy 39, $137-175$

Ibbotson, R.G., 1975. Price performance of common stock new issues. Journal of financial economics 2, 235-272

James, C., 1987. Some evidence on the uniqueness of bank loans. Journal of Financial Economics 19, 217-235

James, C., Wier, P., 1990. Borrowing relationships, intermediation, and the cost of issuing public securities. Journal of Financial Economics 28, 149-171

Johnson, S.A., 1997. The effect of bank reputation on the value of bank loan agreements. Journal of Accounting, Auditing \& Finance 12, 83-100

Johnson, S.A., 1998. The effect of bank debt on optimal capital structure. Financial Management, 4756

Kallunki, J.-P., 1997. Handling missing prices in a thinly traded stock market: implications for the specification of event study methods. European journal of operational research 103, 186-197

Kean, S.E., 2013. SEC Reporting restrictions in the mining industry: An examination of the modelling and value-relevance of gold resource estimtates. UTS Working Paper

Korteweg, A., 2010. The net benefits to leverage. The Journal of Finance 65, 2137-2170

Lee, K.-W., Sharpe, I.G., 2009. Does a Bank's Loan Screening and Monitoring Matter? Journal of Financial Services Research 35, 33-52

Leland, H.E., Pyle, D.H., 1977. Informational Asymmetries, Financial Structure, and Financial Intermediation. The Journal of Finance 32, 371-387

Leuz, C., Verrecchia, R.E., 2000. The economic consequences of increased disclosure. Journal of accounting research, 91-124

Loughran, T.I.M., Ritter, J.R., 1995. The New Issues Puzzle. The Journal of Finance 50, 23-51

Lummer, S.L., McConnell, J.J., 1989. Further evidence on the bank lending process and the capitalmarket response to bank loan agreements. Journal of Financial Economics 25, 99-122

Maskara, P.K., Mullineaux, D.J., 2011. Information asymmetry and self-selection bias in bank loan announcement studies. Journal of Financial Economics 101, 684-694

Masulis, R.W., Korwar, A.N., 1986. Seasoned equity offerings: An empirical investigation. Journal of financial economics 15, 91-118

Maynes, E., Rumsey, J., 1993. Conducting event studies with thinly traded stocks. Journal of Banking \& Finance 17, 145-157

McDonald, J., 1994. Asymmetric Information: The Case of Bank Loan Commitments. Journal of Financial and Strategic Decisions 7, 23-31

Megginson, W.L., Weiss, K.A., 1991. Venture capitalist certification in initial public offerings. The Journal of Finance 46, 879-903

Mester, L.J., Nakamura, L.I., Renault, M., 2007. Transactions accounts and loan monitoring. Review of Financial Studies 20, 529-556

Mikkelson, W.H., Partch, M.M., 1986. Valuation effects of security offerings and the issuance process. Journal of Financial Economics 15, 31-60

Mirabella Nickel Ltd, 2013. Disclosure Policy. Available at http://www.mirabela.com.au/_content/documents/1107.pdf

Mosebach, M., 1999. Market response to banks granting lines of credit. Journal of Banking \& Finance $23,1707-1723$ 
Myers, S.C., Majluf, N.S., 1984. Corporate financing and investment decisions when firms have information that investors do not have. Journal of Financial Economics 13, 187-221

Nakamura, L.I., 1991. Commercial bank information: Implications for the structure of banking.

Preece, D., Mullineaux, D.J., 1996. Monitoring, loan renegotiability, and firm value: The role of lending syndicates. Journal of Banking \& Finance 20, 577-593

Preece, D.C., Mullineaux, D.J., 1994. Monitoring by financial intermediaries: Banks vs. Nonbanks. Journal of Financial Services Research 8, 193-202

Raman, K., Tripathy, N., 1993. The effect of supplemental reserve-based accounting data on the market microstructure. Journal of Accounting and Public Policy 12, 113-133

Ritter, J.R., 1991. The Long-run Performance of Initial Public Offerings. Journal of Finance 46, 3-27

Ross, D.G., 2010. The "dominant bank effect:" How high lender reputation affects the information content and terms of bank loans. Review of financial studies 23, 2730-2756

Ross, S.A., 1977. The determination of financial structure: the incentive-signalling approach. The Bell Journal of Economics, 23-40

Schauer, P.C., 2002. The effects of industry specialization on audit quality: an examination using bidask spreads. Journal of Accounting and Finance Research 10, 76-86

Silver Mines Limited, 2013. Policy on Continuous Disclosure. Available at http://www.silverminesltd.com.au/media/4781/continuous_disclosure.pdf

Slovin, M.B., Johnson, S.A., Glascock, J.L., 1992. Firm size and the information content of bank loan announcements. Journal of Banking \& Finance 16, 1057-1071

Slovin, M.B., Sushka, M.E., Hudson, C.D., 1988. Corporate commercial paper, note issuance facilities, and shareholder wealth. Journal of International Money and Finance 7, 289-302

Slovin, M.B., Sushka, M.E., Hudson, C.D., 1990. External monitoring and its effect on seasoned common stock issues. Journal of Accounting and Economics 12, 397-417

Slovin, M.B., Young, J.E., 1990. Bank lending and initial public offerings. Journal of Banking \& Finance 14, 729-740

Spiess, D.K., Affleck-Graves, J., 1995. Underperformance in long-run stock returns following seasoned equity offerings. Journal of Financial Economics 38, 243-267

Spiess, D.K., Affleck-Graves, J., 1999. The long-run performance of stock returns following debt offerings. Journal of Financial Economics 54, 45-73

Stiglitz, J.E., Weiss, A., 1981. Credit rationing in markets with imperfect information. The American economic review 71, 393-410

Strebulaev, I.A., Yang, B., 2013. The mystery of zero-leverage firms. Journal of Financial Economics Forthcoming

Tufano, P., 1998. The determinants of stock price exposure: Financial engineering and the gold mining industry. The Journal of Finance 53, 1015-1052

View Resources Limited, 2006. Bronzewing poised for redevelopment. Available at http://www.asx.com.au/asxpdf/20061024/pdf/3z4rb03by1yn6.pdf

Winton, A., 1999. Don't put all your eggs in one basket? Diversification and specialization in lending. Diversification and Specialization in Lending (September 27, 1999) 